\title{
Tortonian teleost otoliths from northern Italy: taxonomic synthesis and stratigraphic significance
}

\section{Chien-Hsiang LIN ${ }^{1, *}$, Rostislav BRZOBOHATÝ ${ }^{2}$, Dirk NOLF ${ }^{3}$, Angela GIRONE ${ }^{4}$}

${ }^{1}$ Dipartimento di Scienze della Terra e Geoambientali, Università degli Studi di Bari Aldo Moro, via E. Orabona, 4, 70125 Bari, Italy and Smithsonian Tropical Research Institute,

PO Box 0843-03092, Balboa, Republic of Panama.

${ }^{2}$ Department of Geological Science, Masaryk University, Kotlářská 2, CZ-611 37 Brno, Czech Republic.

${ }^{3}$ Institut royal des Sciences naturelles de Belgique, 29, Rue Vautier, 1000 Brussels, Belgium.

${ }^{4}$ Dipartimento di Scienze della Terra e Geoambientali, Università degli Studi di Bari Aldo Moro, via E. Orabona, 4, 70125 Bari, Italy.

*Corresponding author: chlin.otolith@gmail.com; r97b41028@gmail.com

22Email: rosta@sci.muni.cz

${ }^{3}$ Email: dirk.nolf@scarlet.be

${ }^{4}$ Email: angela.girone@uniba.it

\footnotetext{
${ }^{1}$ urn:Isid:zoobank.org:author:D39077E1-7025-4118-B258-C4A896E63E2A

${ }^{2}$ urn:Isid:zoobank.org:author:A354D828-3D07-46F5-9D27-4F9D7B208F12

${ }^{3}$ urn:1sid:zoobank.org:author:6BCC71A0-1BEE-4BC0-BDFC-D070609DEFAB

${ }^{4}$ urn:1sid:zoobank.org:author:B4212D22-1D1B-48E9-8ABB-C1D1E05573EF
}

\begin{abstract}
The Tortonian fish otoliths of northern Italy have been studied for more than a century and represent one of the best known otolith-based teleost faunas in the Miocene of the Mediterranean Basin. Yet with the growing knowledge on Recent otoliths, an updated taxonomic overview of this fauna is needed. Moreover, new material from hemipelagic Tortonian marls sampled at nine localities is described herein, revealing 109 taxa of which 88 are recognised at species level. Four of these are new: Coryphaenoides biobtusus sp. nov., "Merluccius" rattazzii sp. nov., Neobythites auriculatus sp. nov. and Lesueurigobius stironensis sp. nov. The compilation of previously studied and newly acquired material revealed a total of 118 nominal Tortonian species. At generic level, the fauna is characterised by many modern forms; more than $90 \%$ can be assigned to present day genera. At species level, however, more than half of the represented taxa are extinct. Based on the fossil otolith record, the Tortonian fauna of the Mediterranean is most similar to that of the Langhian (Badenian) of the Central Paratethys by sharing many extinct Miocene species, but it is also very close to that of the Pliocene Mediterranean, by sharing many modern Atlantic-Mediterranean forms. The Tortonian fauna is further characterised by many species that are apparently confined to the upper Miocene, resulting in a unique combination of its taxonomic composition.
\end{abstract}

Keywords. Otolith-based fish fauna, taxonomy, faunal comparison, fossil record analysis, biogeography.

Lin C.-H., Brzobohatý R., Nolf D. \& Girone A. 2017. Tortonian teleost otoliths from northern Italy: taxonomic synthesis and stratigraphic significance. European Journal of Taxonomy 322: 1-44. https://doi.org/10.5852/ ejt.2017.322 


\section{Introduction}

In northern Italy, Tortonian deposits yielding fish otolith are known and have been studied for more than a century (Bassoli 1906; Anfossi \& Mosna 1969a, 1969b; Robba 1970; Anfossi \& Mosna 1971; Nolf \& Steurbaut 1983; Girone et al. 2010; Lin et al. 2015; Lin 2016), revealing an otolith-based fish fauna of about 100 taxa. The fauna from this area thus became the best known in the Mediterranean Basin. The otolith-bearing deposits are mainly hemipelagic marls and attain more than 100 metres of thickness at many places. Additional material from the turbiditic Tortonian deposits intercalated in the hemipelagic marls was reported in Lin et al. (2015).

Due to the opening and obliteration of the oceanic channels in the basin (Rögl 1998, 1999), the Tortonian fish fauna contains both present day Atlantic and Mediterranean species, and, to a lesser extent, IndoPacific elements. This fauna is also characterised by a high number of modern genera, grouping both extant and fossil species (Lin et al. 2015)

The present study emphasises a taxonomic revision by integrating newly acquired material with previously published results, and aims to reconstruct a complete survey of the Tortonian otolithbased fish fauna in this region. A list of updated nominal species is compiled and their stratigraphical and geographical distribution is discussed. Although our compilation of the Tortonian fish fauna is exclusively based on otolith records, there are also several studies dealing with the skeleton-based fish records from the Tortonian of northern Italy (e.g., Gaudant et al. 2007, 2008). The precise relation between the otolith-based taxa and the skeleton-based ones is often not directly evident, and constitutes a topic that largely exceeds the scope of the present study.

\section{Material and methods}

The collecting sites are located in Fig. 1; detailed descriptions and coordinates of each locality are mentioned below. All the samples are stored in the Institut royal des Sciences naturelles de Belgique, Brussels, Belgium (IRSNB).

\section{Locality data}

\section{Alba, Tanaro}

Carta d'Italia 1/25 000, Sheet Alba (69-III SW), $\mathrm{x}=420.600, \mathrm{y}=4950.800\left(44.703415^{\circ} \mathrm{N}, 7.997149^{\circ} \mathrm{E}\right)$.

In the bed of the Tanaro River, near Alba, Tortonian sediments are exposed along several km, from the east of Alba to Roddi (see map in Gaudant et al. 2007, 2008: fig. 1). The area sampled for otoliths is just upstream of a $5 \mathrm{~cm}$-thick outcropping sandstone level, dipping about $6-8^{\circ}$ to the NNW (= downstream). This level was taken as a reference point because it is relatively easy to recognise in the series. In the Tortonian of the Tanaro, finely laminated clays with fish skeletons alternate with more massive clays without lamination. Upstream of the reference sandstone level, laminated clay levels were sampled at $3 \mathrm{~m}$ and at $130 \mathrm{~m}$ (this also means slightly lower in the stratigraphic series) from the reference sandstone bar. The massive clays were sampled at $5 \mathrm{~m}$ and $50 \mathrm{~m}$. Some earlier samples of massive clay in the same zone are less well localised. Because of the high water level at subsequent visits, it was not possible to take additional well localised samples.

The laminated clays contain mainly myctophids and Bregmaceros Thompson, 1840, meso- and epipelagic taxa which are also well-represented in the skeleton materials, but no benthic taxa. The massive clays contain a more varied association with several taxa that are not represented in the laminated clays. Apparently, the laminated clays correspond to anoxic periods, without benthic or burrowing organisms, which explain the undisturbed lamination of the sediment and the preservation of entire skeletons. The massive clays correspond to periods of abundant benthic life and burrowing organisms, which mixed 
the sediment. Beside myctophids and Bregmaceros, these levels also contain a diverse association of benthic fishes.

\section{Costa Vescovato}

Carta d'Italia 1/25 000, Sheet Villalvernia (70-II NE), $x=4$ 94.575, $y=4961.800\left(44.809582^{\circ} \mathrm{N}\right.$, $\left.8.931395^{\circ} \mathrm{E}\right)$.

Surface material collected by B. Rattazzi.

\section{Gallo d'Alba}

Carta d'Italia 1/25 000, Sheet Monforte d'Alba (81-IV NW), $x=419.700, y=4945.850\left(44.661523^{\circ} \mathrm{N}\right.$, $\left.7.987109^{\circ} \mathrm{E}\right)$.

Sample of about $100 \mathrm{~kg}$ of clays screenwashed by O. Cavallo.

\section{Mondovi, Madonna della Neve}

Carta d'Italia 1/25 000, Sheet Carrù (80-II NE), $\mathrm{x}=406.780, \mathrm{y}=4919.980\left(44.427112^{\circ} \mathrm{N}, 7.828848^{\circ} \mathrm{E}\right)$.

The sampled outcrop is in a deeply incised southern tributary of the Rio Branzola (River Branzola). About $1000 \mathrm{~kg}$ of clay was screenwashed at this locality in 1998 by O. Cavallo, P. Hoffman and D. Nolf, which provided several thousand otoliths. The studied interval, originally referred to the Tortonian, was

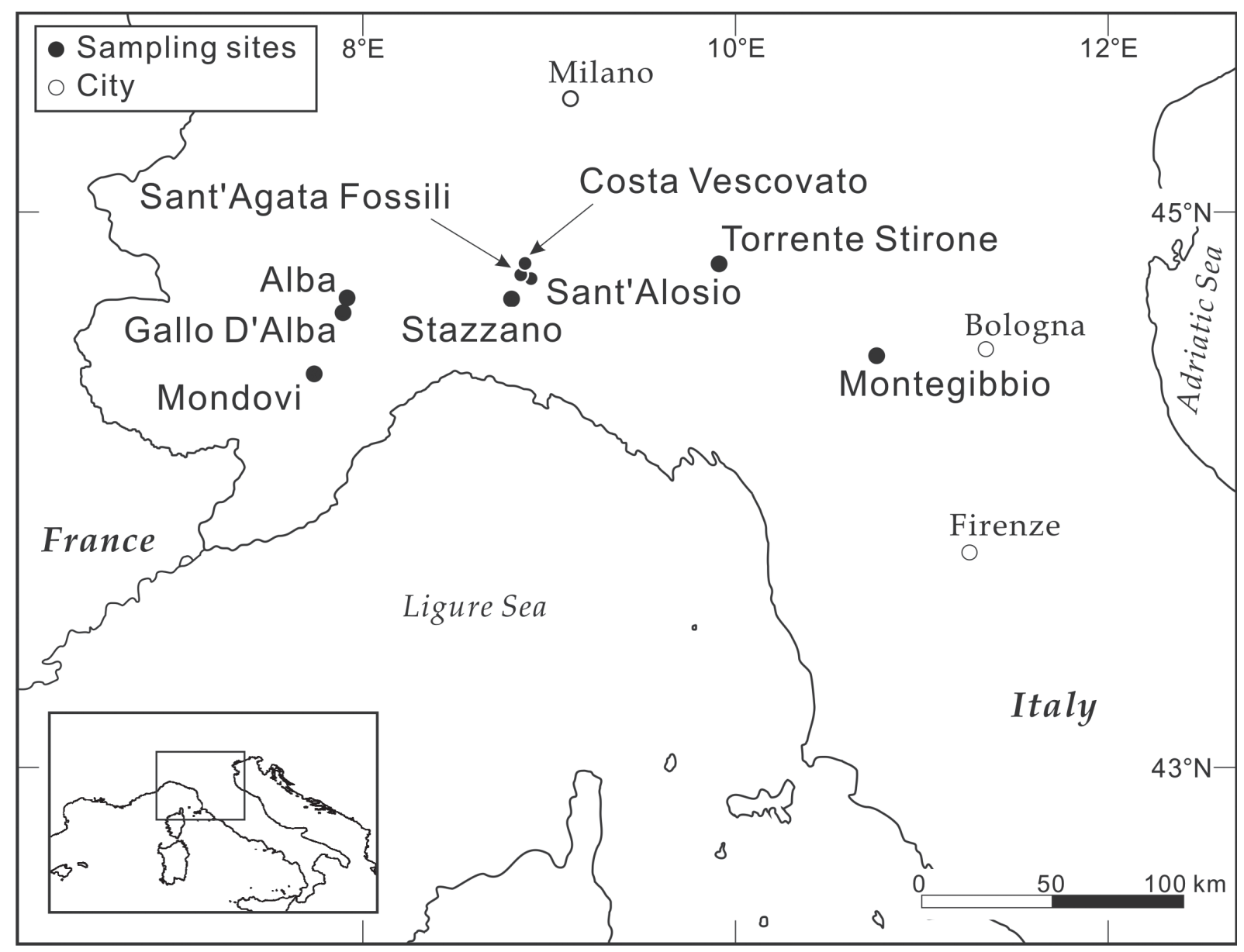

Fig. 1. Map showing the sampling sites. 
attributed to the lower Serravallian by Violanti \& Giraud (1992, their point 20A), and mentioned as such in Brzobohatý \& Nolf (2000: p. 186). New biostratigraphic analyses based on planktonic foraminifera and calcareous nannofossils, however, permit a definitie attribution to the lower Tortonian (D. Violanti, pers. comm.; P. Maiorano, pers. comm.), in particular to the Neogloboquadrina acostaensis Zone according to the biostratigraphic scheme of Iaccarino (1985) and to the MNN9 Zone of calcareous nannoplankton in the biostratigraphic scheme of Fornaciari et al. (1996). This means that the myctophid otoliths considered being of Serravallian age in Brzobohatý \& Nolf (2000) must be referred to the Tortonian.

\section{Montegibbio}

Coordinates: $44.496784^{\circ} \mathrm{N}, 10.777845^{\circ} \mathrm{E}$.

This locality is the same locality described in Nolf \& Steurbaut (1983: fig. 1), additional material collected by R. Marquet is herein included.

\section{Sant'Agata Fossili}

Carta d'Italia $1 / 25$ 000, Sheet Villalvernia (70-II NE), $x=494.120, y=4959.300\left(44.785312^{\circ} \mathrm{N}\right.$, $\left.8.925417^{\circ} \mathrm{E}\right)$.

Material studied by Nolf \& Steurbaut (1983) and additionally collected material.

\section{Sant'Alosio, erosional cliffs East of Sant'Alosio village}

Carta d'Italia 1/25 000, Sheet Garbagna (71-III NW), $x=496.550, y=4960.000\left(44.793131^{\circ} \mathrm{N}\right.$, $\left.8.952830^{\circ}\right)$.

At this site, surface material was collected by B. Rattazzi and sediments were screenwashed by O. Cavallo.

\section{Stazzano}

Carta d'Italia 1/25 000, Sheet Serravalle Scrivia (70-II SE), $x=490.120, y=4953.000\left(44.727756^{\circ} \mathrm{N}\right.$, $\left.8.873516^{\circ} \mathrm{E}\right)$.

Clays with turbiditic material, containing many shells. A sediment sample of about $50 \mathrm{~kg}$ was collected by D. Nolf, E. Steurbaut, G. Pavia and E. Robba in 1984.

\section{Torrente Stirone}

Carta d'Italia 1/25 000, Sheet Fidenza (73-IV SW), $x=575.700, y=4965.775\left(44.840139^{\circ} \mathrm{N}\right.$, $\left.9.955793^{\circ} \mathrm{E}\right)$.

The analysed sediments consist of glauconitic sandy clay. The biostratigraphic analysis based on planktonic foraminifera attributes them to the upper Tortonian/lower Messinian (N17, Globorotalia suturea/Globorotalia mediterranea Zone) (E. Bicchi, pers. comm.). Further biostratigraphic analysis based on calcareous nannofossils furnished a probable attribution to the Tortonian NN10 Nannoplankton Zone (E. Martini, pers. comm.).

\section{Results}

\section{Systematic paleontology}

The classification follows Nelson (2006). The abbreviation aff. (affinis) is used when well-preserved specimens could not unequivocally be attributed to known species, whereas cf. (conformis) is inserted when the preservation is too poor for a conclusive identification. In the subsequent analyses, however, these taxa are treated in the same way as taxa without the aff. or cf. insertion. For species of uncertain 
generic position, we follow the system already published in Lin et al. (2016), in order to comply completely with the ICZN Code. In this approach, species that can only be allocated at family level (or higher-ranking level), but not attributed to a precise Recent genus, are designated by the type genus of the concerned family (or subfamily, etc.), between inverted commas, instead of the open generic nomenclature applied in Nolf (2013), in which the generic designations are not genera in the sence of the ICZN Code, e.g., "Gobiida" bicornuta Lin et al., 2015 is converted to "Gobius" bicornutus (Lin et al., 2015), where "Gobius" stands for an incertae sedis gobiid. For reasons of logical consistency within the present paper, all species that were previously described in open generic nomenclature have been converted to the system required by the ICZN Code for use in our text, plus Tables 1 and 2. A list of these species is given in the Appendix.

\section{Description of new species}

Order Gadiformes Goodrich, 1909

Family Macrouridae Bonaparte, 1832

Subfamily Macrourinae Bonaparte, 1831

Genus Coryphaenoides Gunnerus, 1765

Coryphaenoides biobtusus sp. nov. urn:1sid:zoobank.org:act:58E20EDF-1778-4704-924E-886C4028B5A1

Fig. 8E-F

\section{Diagnosis}

This species is characterised by nearly rectangular and thickset otoliths. The anterior rim of the otoliths is blunt, which makes the highest part of the otolith at the anterior portion. The dorsal rim undulates, with the middle part being concave, while both the anterior and posterior parts are higher and angular. The posterior rim is rounded, smaller than the anterior one. The sulcus is filled with two large elongate collicula.

\section{Etymology}

The species epithet is derived from the Latin 'biobtusus, a, um', which means obtuse (or blunt) on both sides, alluding to the blunt anterior and posterior rims of the otoliths.

\section{Type material examined}

\section{Holotype}

ITALY: a left otolith (IRSNB P 9684, Fig. 8E).

\section{Paratype}

ITALY: 1 specimen (IRSNB P 9685, Fig. 8F).

\section{Type locality and horizon}

ITALY: Tortonian Clay at Alba, Tanaro River (massive clays, $5 \mathrm{~m}$ upstream of reference sandstone ledge).

\section{Dimensions of the holotype}

Length $=4.95 \mathrm{~mm}$, height $=3.05 \mathrm{~mm}$, thickness $=1.35 \mathrm{~mm}$.

\section{Description}

The otoliths are very thick. The inner face is slightly convex; the outer face is markedly convex in all directions, but with the strongest convexity in the antero-posterior direction (Fig. 8E1). The anterior rim 


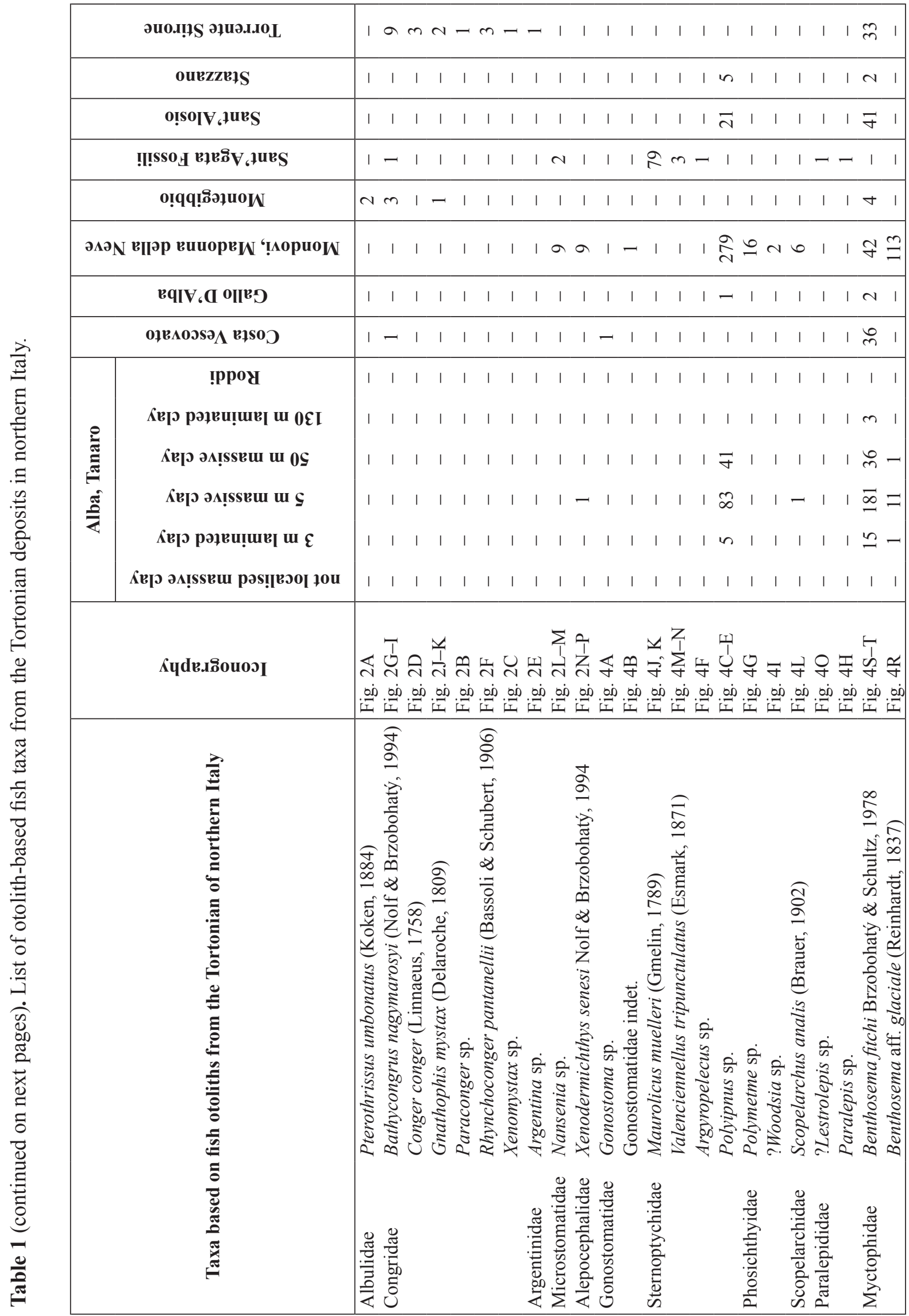


LIN C.-H. et al., Tortonian otoliths from northern Italy

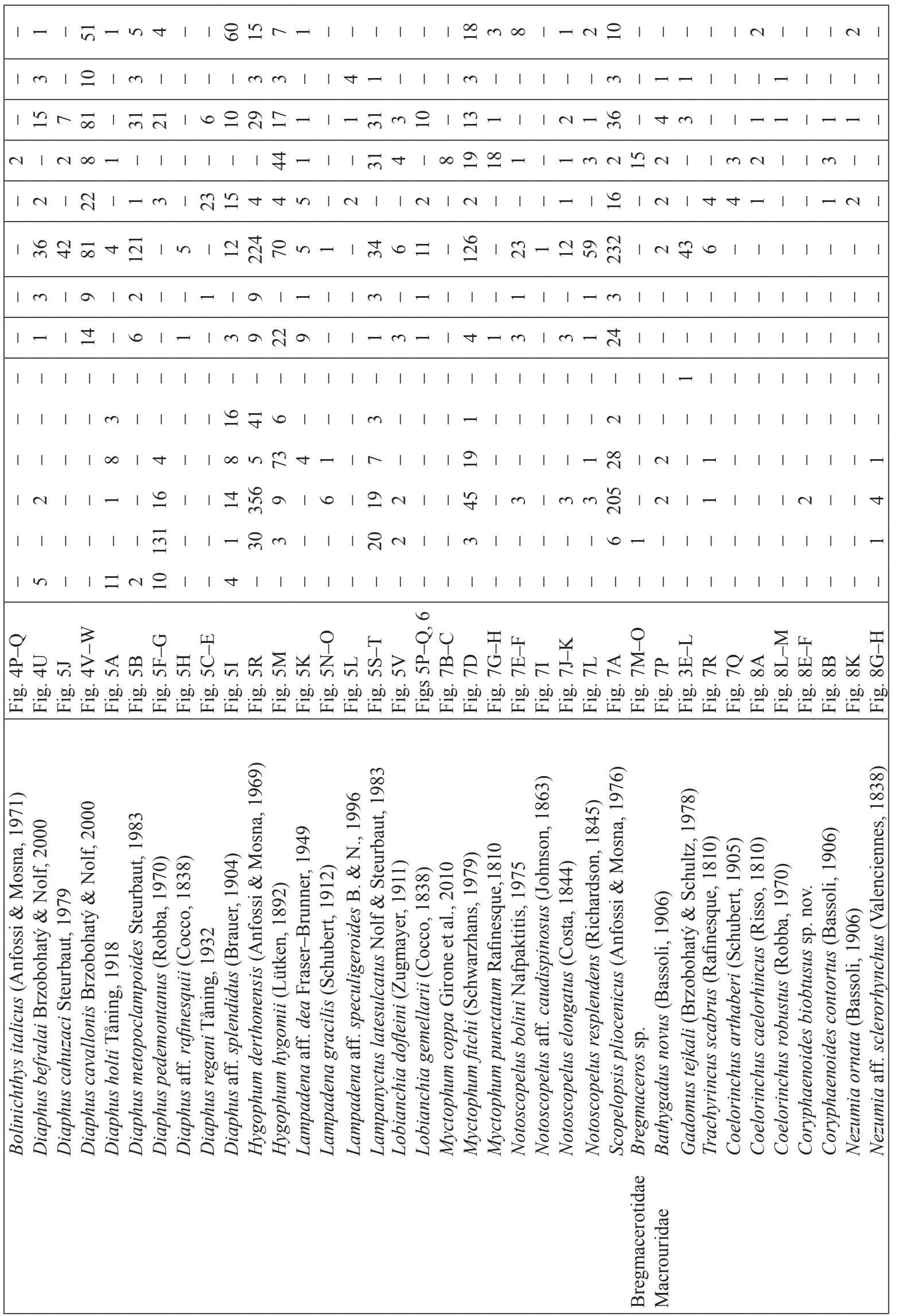


European Journal of Taxonomy 322: 1-44 (2017)

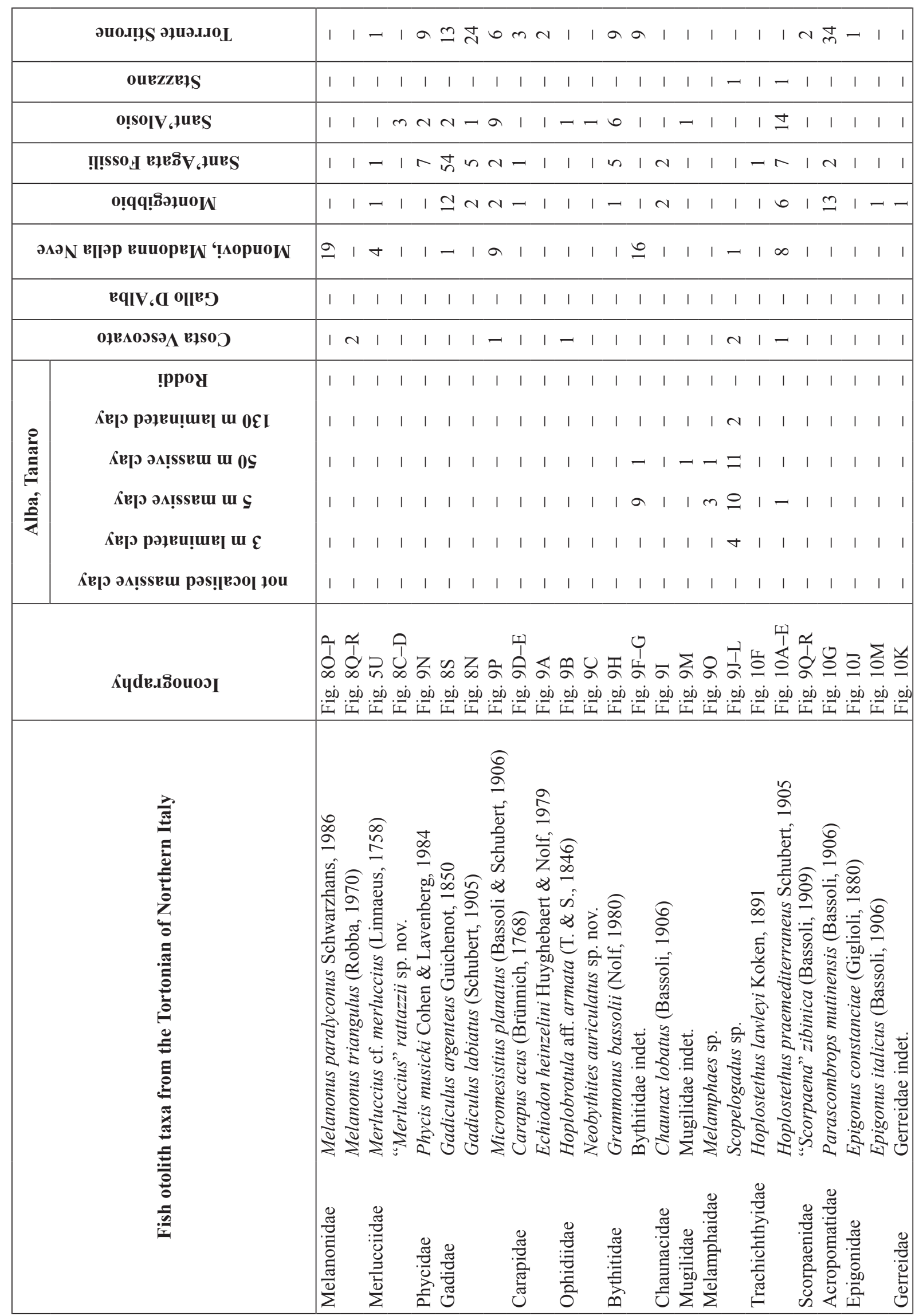




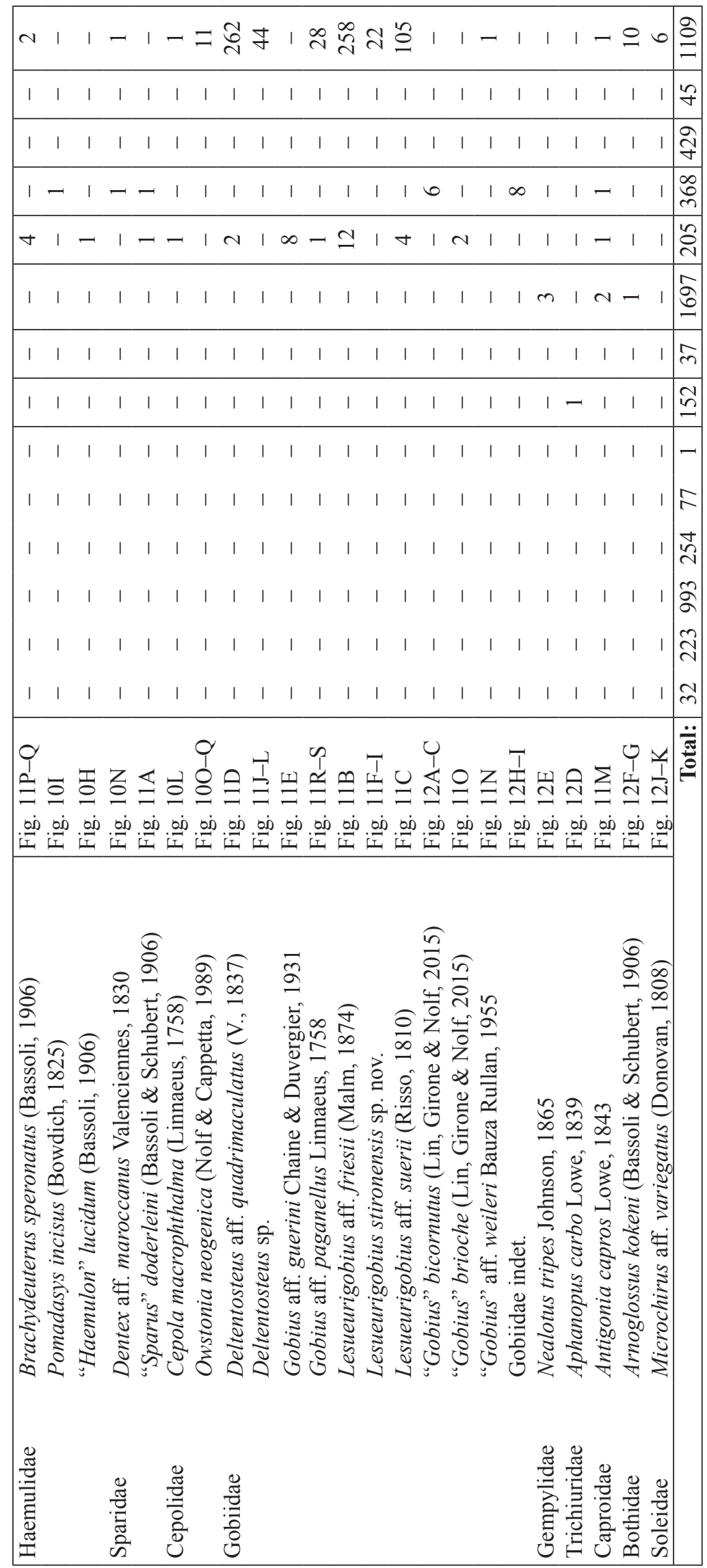


of the otolith is oblique, bears a blunt rostrum, and slightly protrudes in its ventral part; the posterior rim is blunt and shorter than the anterior one. The ventral rim is smooth, curving gently upwards in its posterior portion. The sulcus is pince-nez-shaped (pince-nez is a kind of glasses without ear branches that are worn by pinching the nose), rather shallow, and with unclear ends at both the anterior and the posterior ends. The cristae are well-marked. The collicula are large, highly elevated, nearly rectangular in shape, and lie symmetrical to the junction between ostium and cauda. The dorsal area is narrower than the ventral one. A deep ventral furrow running along the ventral rim is especially evident in the paratype.

\section{Remarks}

These two well-preserved otoliths represent adult specimens of this species, which allow a reasonable assignment to the genus Coryphaenoides Gunnerus, 1765. In some Recent species, for example in C. armatus (Hector, 1875) (see Nolf 2013: pl. 92), the general outline of the otolith and the sulcus configuration are comparable to that of this fossil species.

Family Merlucciidae Rafinesque, 1815

Subfamily Merlucciinae Rafinesque, 1815

Type genus Merluccius Rafinesque, 1810.

"Merluccius" rattazzii sp. nov. urn:1sid:zoobank.org:act:658A81A3-5E45-4D56-B3C6-DF85AA002A5D

Fig. 8C-D

\section{Diagnosis}

The species is characterised by elongate otoliths. The highest part of the otolith is in the middle of the dorsal rim. The thickest portion of the otolith is near the junction of the ostium and cauda. The pincenez-shaped sulcus is characterised by an elliptic ostial colliculum and a much longer, dorsally directed caudal colliculum.

\section{Etymology}

This species is named in honor of Bruno Rattazzi, who collected the type specimens.

\section{Type material examined}

\section{Holotype}

ITALY: a right otolith (IRSNB P 9686, Fig. 8C).

\section{Paratypes}

ITALY: two specimens, of which one is figured (IRSNB P 9687, Fig. 8D).

\section{Type locality and horizon}

ITALY: Tortonian Clay at Sant' Alosio, surface collected.

\section{Dimensions of the holotype}

Length $=13.35 \mathrm{~mm}$, height $=5.15 \mathrm{~mm}$, thickness $=1.85 \mathrm{~mm}$.

\section{Description}

The otoliths of this species are large and elongate. They are moderately thick, with a convex inner face and a flat outer face. The anterior rim is rounded and the posterior rim, which is higher than the anterior one, is blunt. The ventral rim is gently curved; the dorsal rim is highest in the middle, and gently 
becomes lower at the anterior and posterior parts. The margins of all the rims are smooth. The sulcus is large, pince-nez-shaped, and deep; the delimitation of the sulcus becomes less clear at the anterior end. There is a channel opening dorsally at the antero-dorsal part of the ostium. The crista superior is wellmarked, with its central part the most prominent and marking its lowest trajectory; the crista inferior is somewhat less salient in its central part. The collicula are both well developed and their margins are well-separated from the cristae. The ostial colliculum is elliptic and lies more or less horizontally, while the caudal one is elongate, widened and dorsally directed in its posterior part. The dorsal depression is small and shallow.

\section{Remarks}

The here described otoliths are apparently related to the merlucciids (subfamily Merlucciinae), like the Recent Merluccius and the extinct genus Palaeogadus Rath, 1859, but they differ from those of Merluccius by their very smooth margins and their rounded anterior and posterior portions, while otoliths of Palaeogadus show more elongate otoliths with markedly acuminated anterior and posterior portions and well-developed rostrums. In addition, the otoliths of Palaeogadus have a very large and high cauda as opposed to those of Merluccius where their ostium and cauda are of roughly the same size, but this is a more variable feature (see Nolf 2013: pls 101-104). The new species apparently belong to an extinct deep-water taxon of the merlucciids.

Order Ophidiiformes Berg, 1937

Suborder Ophidioidei Berg, 1937

Family Ophidiidae Rafinesque, 1810

Subfamily Neobythitinae Radcliffe, 1913

Genus Neobythites Goode \& Bean, 1885

Neobythites auriculatus sp. nov. urn:Isid:zoobank.org:act:06D09029-80AE-461E-9135-01594A825560

Fig. 9C

\section{Diagnosis}

The species is characterised by very elongate otoliths with moderate thickness. The highest part of the otolith is in the middle. Both the dorsal and ventral rims are curved. The huge, wide sulcus bears a large and oblong ostial colliculum and a much shorter, oval caudal colliculum.

\section{Etymology}

The species epithet is derived from the Latin 'auriculatus, a, um': having ears; alludes to the two obtuse little spines at both the anterior and posterior ends of the dorsal rim, suggesting two small ears.

\section{Type material examined}

\section{Holotype}

ITALY: a left otolith, the only known specimen (IRSNB P 9688, Fig. 9C).

\section{Type locality and horizon}

ITALY: Tortonian Clay at Sant' Alosio, surface collection.

\section{Dimensions of the holotype}

Length $=19.75 \mathrm{~mm}$, height $=10.30 \mathrm{~mm}$, thickness $=3.60 \mathrm{~mm}$. 


\title{
Description
}

The holotype is a very large elongate elliptic otolith. It is moderately thick, with a convex inner face and concave outer face, but on the outer face, a swollen structure is observed in the middle of the ventral portion (Fig. 9C1). The anterior rim is short and rounded; the posterior rim, which is more or less straight at the extended end, bears two lobes. The dorsal and ventral rims are gently curved, so that the otoliths are widest in the middle. The margin of the ventral rim is smooth. There are two small protrusions at the anterior and posterior angles of the dorsal rim. The sulcus is wide, occupies about one-third of the inner face, and is completely filled by collicula. The cristae are well marked. The collicula are both well developed, but are not completely separated at the collum. Only a large constriction of the crista inferior delimits the ostial and caudal portion. The surface of collicula is irregular. The caudal colliculum is short and oval; the ostial colliculum is about four times as long as the caudal one. The ventral area is wider than the dorsal one.

\section{Remarks}

This huge otolith apparently belongs to an adult (old) individual of an extinct species and it shows most similarity to those of the Recent genus Neobythites Goode \& Bean, 1886.

\author{
Order Perciformes Bleeker, 1859 \\ Suborder Gobioidei Jordan \& Evermann, 1896 \\ Family Gobiidae Cuvier, 1816 \\ Genus Lesueurigobius Whitley, 1950 \\ Lesueurigobius stironensis sp. nov. \\ urn:1sid:zoobank.org:act:CCEB6FA7-DA02-47B3-8A38-D7CA369E9E79
}

Fig. 11F-I

\section{Diagnosis}

This species is characterised by high, pentagonal otoliths. The shape of the dorsal rim is very characteristic in bearing 4-6 large lobes, with the highest one located at the middle and lowering towards both ends. The other rims are nearly straight and perpendicular to each other. The sulcus is deep and ventrally directed at the anterior.

\section{Etymology}

The species is named after its type locality, the Torrente Stirone.

\section{Type material examined}

\section{Holotype}

ITALY: a left otolith (IRSNB P 9689, Fig. 11F).

\section{Paratypes}

ITALY: 21 specimens of which 3 are figured (IRSNB P 9690-P 9692, Fig. 11G-I).

\section{Type locality and horizon}

ITALY: Tortonian Clay exposed in the Torrente Stirone.

\section{Dimensions of the holotype}

Length $=1.75 \mathrm{~mm}$, height $=1.80 \mathrm{~mm}$, thickness $=0.55 \mathrm{~mm}$. 


\title{
Description
}

The otoliths are tall and pentagonal. The dorsal rim bears 4-6 large lobes; the largest and highest lobe and highest lobe is located in the middle and marks the highest point of the otolith. The anterior and posterior rims are almost straight, and the ventral rim is straight in the holotype but very slightly curved in some of the paratypes (e.g., Fig. 11I). In some specimens, however, the anterior rim is crenulated at the lower part and a small concavity is observed in the middle part of the posterior rim (e.g., Fig. 11G). The inner face is more or less flat; the outer face is convex. The sulcus is deep, clearly delimited, and well-divided into ostium and cauda; the anterior part of the ostium is directed ventrally. The cristae are well-developed. The ostium is large and expanded ventrally, with a concavity at the antero-dorsal margin. The cauda is rod-like and rounded at the posterior end. There is a marked swollen collicular crest just below the cauda.

\section{Remarks}

The otoliths of this new species are easily recognised and the shape of the dorsal rim is consistent regardless of size among the available material. The sulcus shape and a slightly asymmetric dorsal rim of the otoliths are the main reasons for attributing this new species to the genus Lesueurigobius. Several Lesueurigobius otoliths have been reported from the Miocene of the Mediterranean (e.g., Reichenbacher \& Cappetta 1999: pl. 3, figs 1-5, L. vicinalis (Koken, 1891); Hoedemakers \& Batllori 2005: pl. 11, figs 9-13, Lesueurigobius sp.), but none of them present the characteristic morphology of the dorsal rim as our new species.

\section{Remarks on taxa requiring comments}

Order Anguilliformes Regan, 1909

Family Congridae Kaup, 1856

Genus Xenomystax Gilbert, 1891

\section{Xenomystax sp.}

A massive, thick otolith is referred to the genus Xenomystax Gilbert, 1891 (Fig. 2C). The specimen is elliptic and elongate with nearly smooth margins. It is characterised by a rather pointed and extended anterior end and a rounded and robust posterior part. A well-marked and deep dorsal depression on the high dorsal area is observed. The sulcus is wide, oval and situated at the center of the otolith. Otoliths of three Recent species of Xenomystax are illustrated (Fig. 3A-D, M-O) for comparison. The fossil specimen is most similar to that of X. congroides Smith \& Kanazawa, 1989 (Fig. 3M-N), a western Atlantic species, but differs in showing a shallower and more elongate outline and a more extended anterior part.

\author{
Order Argentiniformes Bertelsen, 1958 \\ Family Argentinidae Bonaparte, 1846 \\ Genus Argentina Linnaeus, 1758
}

\section{Argentina sp.}

Two closely related species of the family Argentinidae with very similar otolith morphology exist in the modern Mediterranean: Argentina sphyraena Linnaeus, 1758 and Glossanodon leioglossus (Valenciennes, 1848) (Whitehead et al. 1986-1989). The main differences between the otoliths of these Recent species are a longer posterior rim and a somewhat weaker postero-ventral angle in those of A. sphyraena (see Nolf 2013: pl. 39 for otoliths of both species; Hoedemakers \& Schneider 2016: fig. 4 for ontogenetic variability of $A$. sphyraena). Therefore, the fossil otolith showing closer similarities to these features is referred to Argentina sp. (Fig. 2E). The broken rostral end does not allow a definite attribution at species level. 


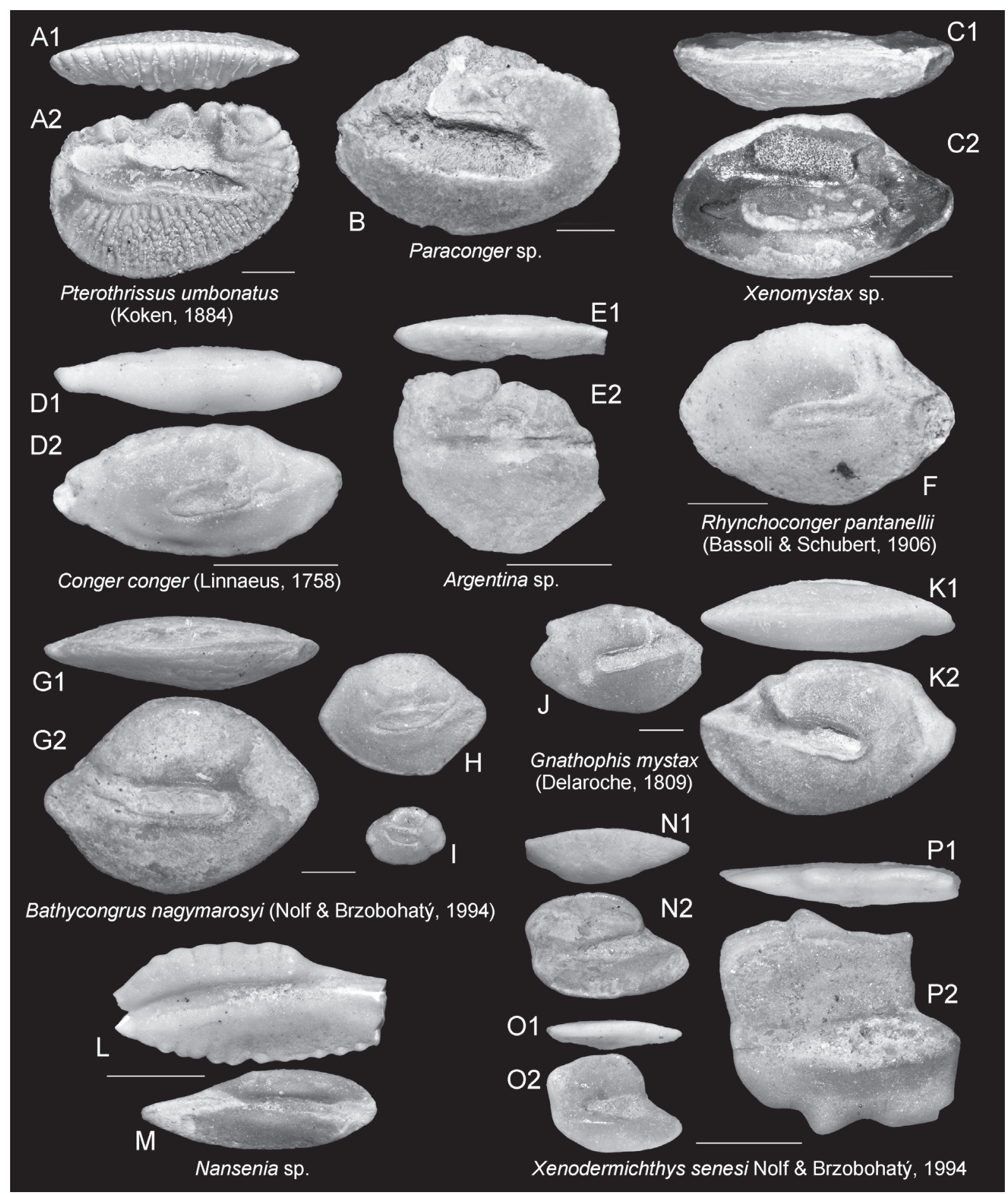

Fig. 2. Tortonian fish otoliths from northern Italy. A. Pterothrissus umbonatus (Koken, 1884), Montegibbio (IRSNB P 9855). B. Paraconger sp., Torrente Stirone (IRSNB P 9856). C. Xenomystax sp., Torrente Stirone (IRSNB P 9857). D. Conger conger (Linnaeus, 1758), Torrente Stirone (IRSNB P 9858). E. Argentina sp., Torrente Stirone (IRSNB P 9859). F. Rhynchoconger pantanellii (Bassoli \& Schubert, 1906), Torrente Stirone (IRSNB P 9860). G-I. Bathycongrus nagymarosyi (Nolf \& Brzobohatý, 1994), Torrente Stirone (IRSNB P 9699-P 9701). J-K. Gnathophis mystax (Delaroche, 1809), Torrente Stirone (IRSNB P 9702-P 9703). L-M. Nansenia sp., Mondovi, Madonna della Neve (IRSNB P 9704-P 9705). N-P. Xenodermichthys senesi Nolf \& Brzobohatý, 1994, Mondovi, Madonna della Neve (IRSNB P 9706-P 9708). 1 = ventral view; $2=$ inner view. Scale bars $=1 \mathrm{~mm}$. 

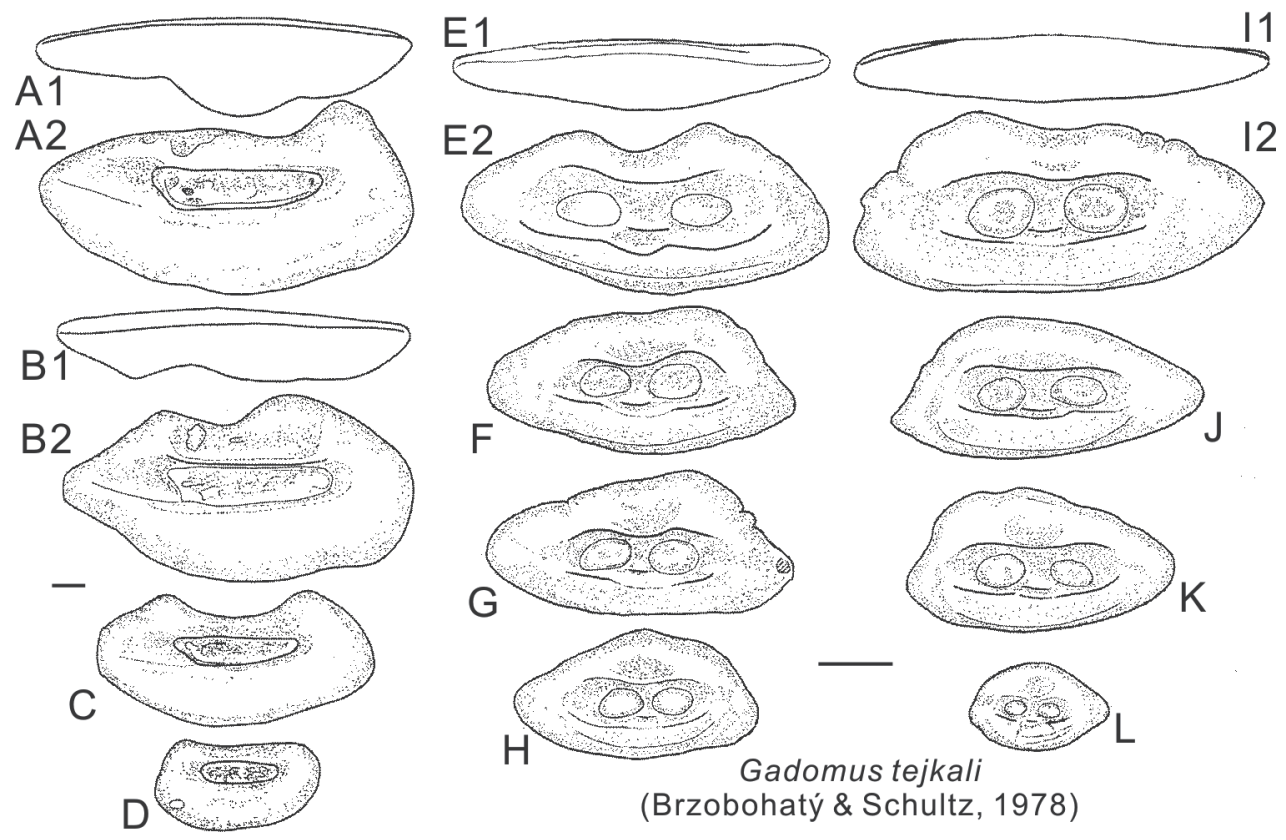

Xenomystax atrarius Gilbert, 1891

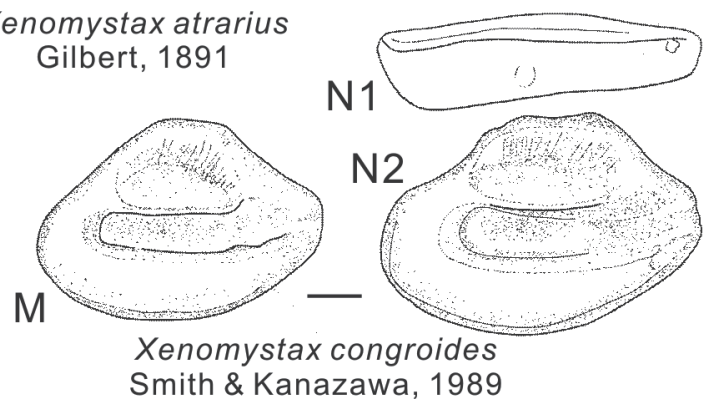

(Brzobohatý \& Schultz, 1978)

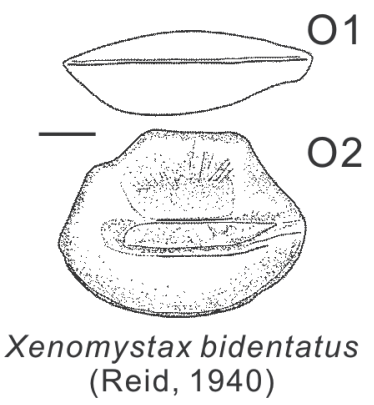

Fig. 3. A-D, M-O. Recent otoliths of species of Xenomystax Gilbert, 1891. A-D. X. atrarius Gilbert, 1891 from Peru, fish total length (TL) $81 \mathrm{~cm}, 72 \mathrm{~cm}, 57 \mathrm{~cm}$ and $43 \mathrm{~cm}$, respectively. M-N. X. congroides Smith \& Kanazawa, 1989, from off Mississippi. O. X. bidentatus (Reid, 1940), from the Caribbean Sea, TL $48 \mathrm{~cm}$. - E-L. Fossil otoliths of Gadomus tejkali (Brzobohatý \& Schultz, 1978) (IRSNB P 9847-P 9854) growth series from Roddi (E) and Mondovi, Madonna della Neve (F-L). 1 = ventral view; 2 = inner view. Scale bars $=1 \mathrm{~mm}$.

Family Alepocephalidae Valenciennes, 1846

Genus Xenodermichthys Günther, 1878

Xenodermichthys senesi Nolf \& Brzobohatý, 1994

A large specimen (Fig. 2P) in our material is somewhat higher in its overall shape and the antero-dorsal angle is more pronounced than those of the similar-sized Chattian type specimens from the Aquitaine Basin, southwest France (Nolf \& Brzobohatý 1994: pl. 2, figs 5, 11); the smaller specimens in our material (Fig. $2 \mathrm{~N}-\mathrm{O}$ ) are characterised by thick otoliths and a convex outer face, and are reasonably similar to the type series from Aquitaine (Nolf \& Brzobohatý 1994: pl. 2, figs 6-10). Because modern alepocephalid otoliths commonly show a great intraspecific variability (e.g., Nolf \& Brzobohatý 1994: pl. 2, figs 1-4), the specimens in question are all assigned to $X$. senesi. The studied material, including large and small specimens, allows us to refer the otoliths figured by Lin et al. (2015: fig. 2(5), as Xenodermichthys aff. copei (Gill, 1884)) to juvenile specimens of $X$. senesi. 
Order Stomiiformes Regan, 1909

Family Phosichthyidae Weitzman, 1974

Genus Woodsia Grey, 1959

\title{
?Woodsia sp.
}

The otolith (Fig. 4I) is most similar to the fossil W. emi Brzobohaty \& Nolf, 2002 from the Langhian of Moravia (Brzobohatý \& Nolf 2002: pl. 2, figs 16-17), but its large and irregularly lobed ventral part does not allow an unambiguous identification.

\author{
Order Aulopiformes Rosen, 1973 \\ Family Paralepididae Bonaparte, 1835
}

A paralepidid otolith from Sant'Agata Fossili (Fig. 4O) is characterised by a very elongate shape, by a large ostial colliculum reaching to the antero-dorsal rim, and by a swollen ventral area. It shows much similarity with otoliths of the Recent genus Lestrolepis (see Smale et al. 1995: pl. 16, figs C1, C2; Lin \& Chang 2012: pls 9, 77). However, the available specimen is too worn for an unambiguous generic attribution. Another paralepidid otolith (Fig. 4H), which is clearly different from the above-mentioned specimen, can be referred to the genus Paralepis (see Girone et al. 2010: fig. 6), but the preservation status does not allow any specific attribution.

Order Myctophiformes Regan, 1911

Family Myctophidae Gill, 1893

Genus Diaphus Eigenmann \& Eigenmann, 1890

The otoliths of Diaphus holti Tåning, 1918 are characterised by a large dorsal area with somewhat pointed dorsal rim at mid-point, which makes their overall shape higher than other Diaphus otoliths (see Schwarzhans 2013a: pl. 3, figs 4, 5 for figured Recent specimens). Although somewhat more compact in the posterior part, several of our juvenile Diaphus otoliths (e.g., Fig. 5A) are recognised as D. holti Tåning, 1918, based on the feature mentioned above. Furthermore, they are very similar to the one figured by Brzobohatý \& Nolf (2000: pl. 3, fig. 9).

The otoliths of Diaphus aff. rafinesquii (Cocco, 1838) show reasonable similarities with those of Recent (see Schwarzhans 2013a: pl. 3, figs 7-10) and Plio-Pleistocene specimens (Brzobohatý \& Nolf 2000: pl. 3, figs 11-13). Our material, however, is poorly preserved, and the dorsal rim of the figured otolith (Fig. $5 \mathrm{H}$ ) is somewhat higher than that of the Recent ones. Moreover, the Recent specimens have a more gently curved dorsal rim than the Tortonian specimens.

Brzobohatý \& Nolf (2000: 192) mentioned that some juvenile otoliths from the Mediterranean Tortonian deposits could possibly be attributed to Diaphus regani Tåning, 1932. This attribution was not convincing, because only juvenile specimens were available. The otoliths of $D$. regani are characterised by a widely expanded antero-dorsal area and a narrower postero-dorsal area, making their highest point along the dorsal rim before the mid-point (Nolf \& Aguilera 1998: pl. 5, figs 1-6; Schwarzhans 2013a: pl. 10, figs 12-16). Our Tortonian specimens (Fig. 5C-E) are not common at all the localities, but they include both small and large specimens with characteristic features that now allow the attribution to the Recent D. regani.

Schwarzhans \& Aguilera (2013) synonymised Diaphus cahuzaci Steurbaut, 1979 (see Steurbaut 1979: pl. 4, figs 1-6) with Diaphus austriacus (Koken, 1891), disregarding the remarks of Nolf $(1985,2013)$ that the latter species (firstly described as Otolithus (Berycidarum) austriacus) is a doubtful species. The 


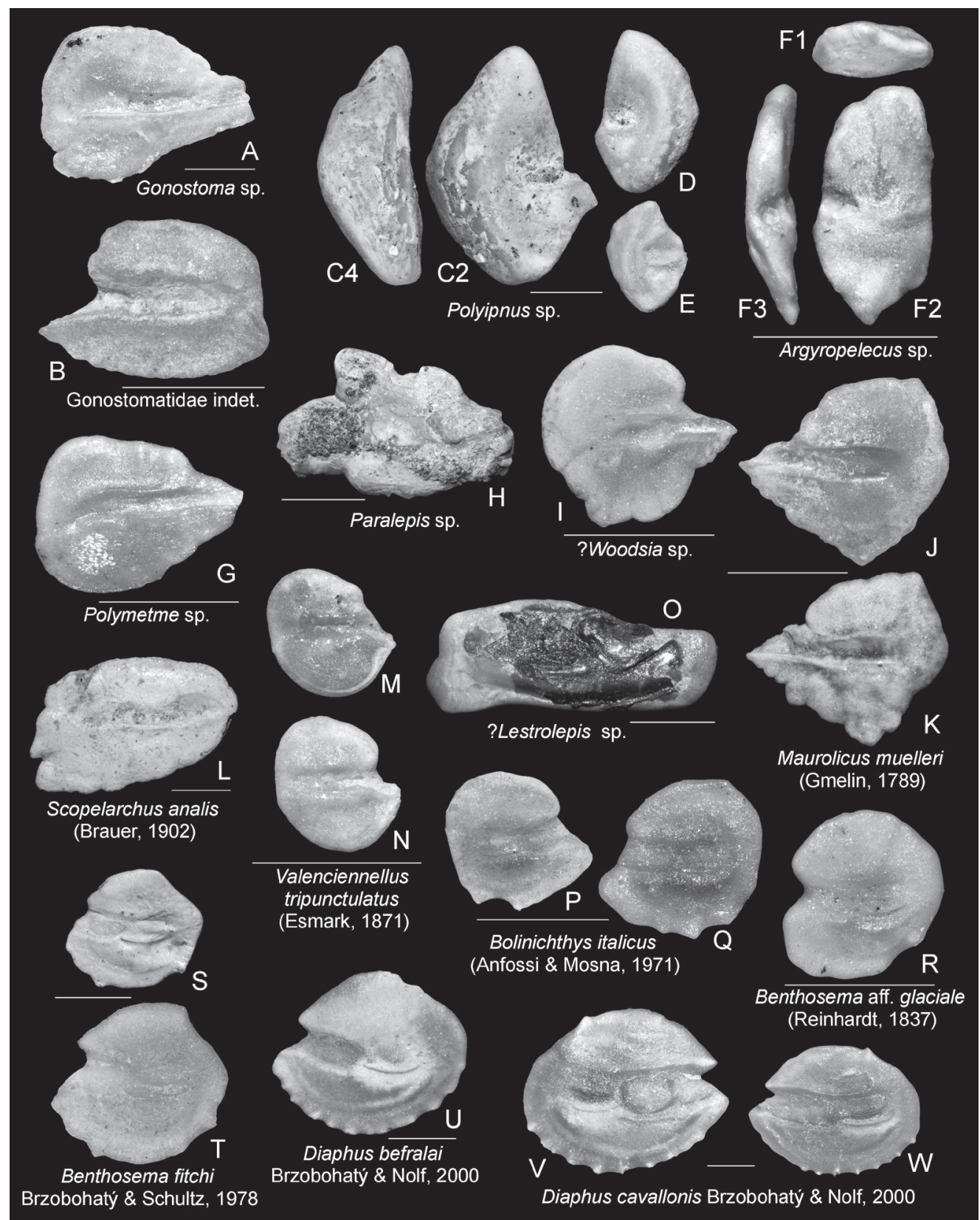

Fig. 4. Tortonian fish otoliths from northern Italy. A. Gonostoma sp., Costa Vescovato (IRSNB P 9709). B. Gonostomatidae indet., Mondovi, Madonna della Neve (IRSNB P 9710). C-E. Polyipnus sp.; C. Sant'Alosio, D-E. Stazzano (IRSNB P 9711-P 9713). F. Argyropelecus sp., Sant'Agata Fossili (IRSNB P 9714). G. Polymetme sp., Mondovi, Madonna della Neve (IRSNB P 9715). H. Paralepis sp., Sant'Agata Fossili (IRSNB P 9716). I. ? Woodsia sp., Mondovi, Madonna della Neve(IRSNB P 9717). J-K. Maurolicus muelleri (Gmelin, 1789), Sant'Agata Fossili (IRSNB P 9718-P 9719). L. Scopelarchus analis (Brauer, 1902), Mondovi, Madonna della Neve (IRSNB P 9720). M-N. Valenciennellus tripunctulatus (Esmark, 1871), Sant'Agata Fossili (IRSNB P 9721-P 9722). O. ?Lestrolepis sp., Sant'Agata Fossili (IRSNB P 9723). P-Q. Bolinichthys italicus (Anfossi \& Mosna, 1971), Sant'Agata Fossili (IRSNB P 9724-P 9725). R. Benthosema aff. glaciale (Reinhardt, 1837), Mondovi, Madonna della Neve (IRSNB P 9726). S-T. Benthosema fitchi Brzobohatý \& Schultz, 1978; S. Costa Vescovato, T. Sant'Alosio (IRSNB P 9727-P 9728). U. Diaphus befralai Brzobohatý \& Nolf, 2000, Mondovi, Madonna della Neve (IRSNB P 9729). V-W. Diaphus cavallonis Brzobohatý \& Nolf, 2000, Costa Vescovato (IRSNB P 9730-P 9731). $1=$ ventral view; $2=$ inner view; $3=$ anterior view; $4=$ posterior view. Scale bars $=1 \mathrm{~mm}$. 


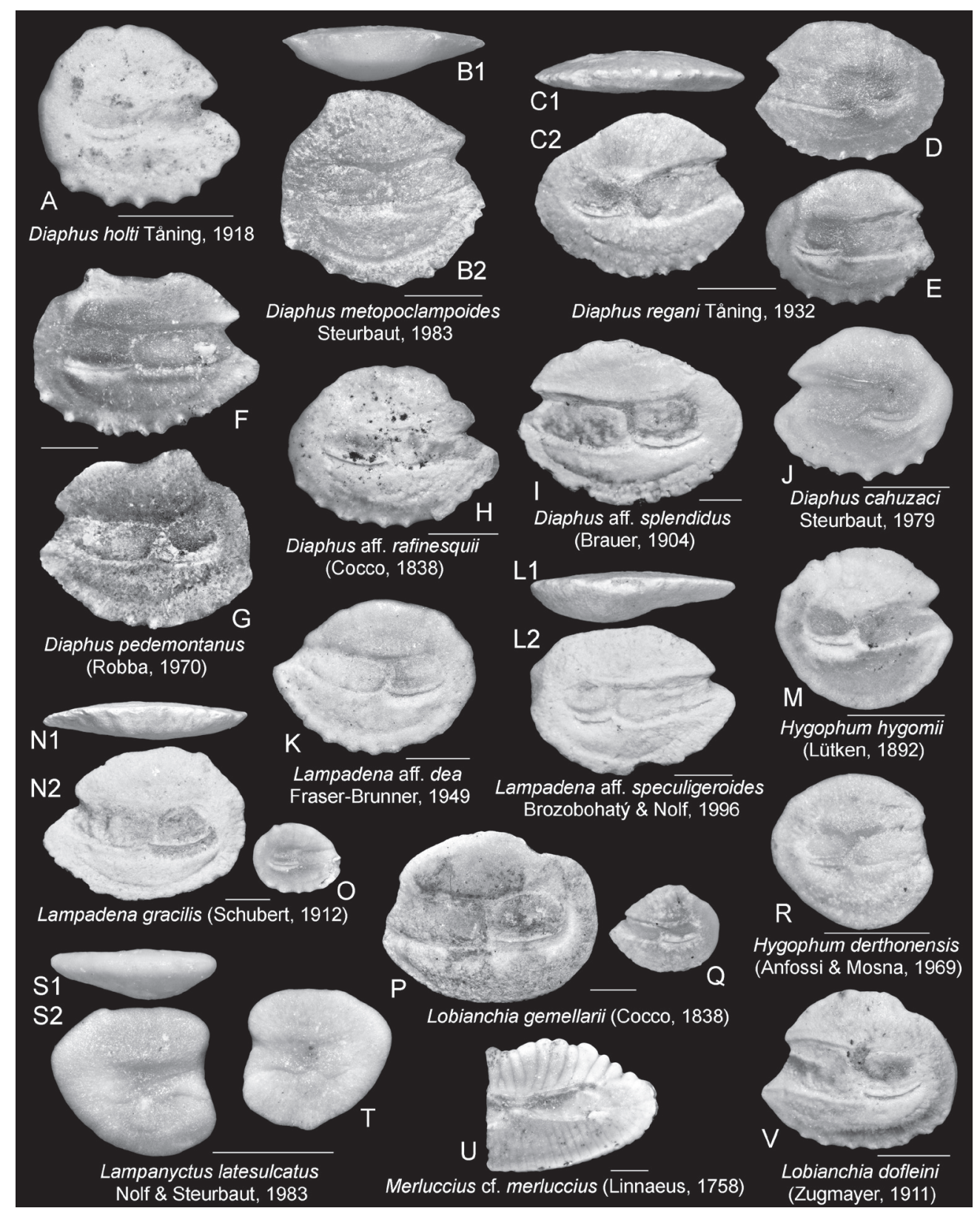

Fig. 5. Tortonian fish otoliths from northern Italy. A. Diaphus holti Tåning, 1918, Mondovi, Madonna della Neve (IRSNB P 9732). B. Diaphus metopoclampoides Steurbaut, 1983, Sant'Alosio (IRSNB P 9733). C-E. Diaphus regani Tåning, 1932, Montegibbio (IRSNB P 9734-P 9736). F-G. Diaphus pedemontanus (Robba, 1970), Sant'Alosio (IRSNB P 9737-P 9738). H. Diaphus aff. rafinesquii (Cocco, 1838), Mondovi, Madonna della Neve (IRSNB P 9739). I. Diaphus aff. splendidus (Brauer, 1904), Costa Vescovato (IRSNB P 9740). J. Diaphus cahuzaci Steurbaut, 1979, Mondovi, Madonna della Neve(IRSNB P 9741). K. Lampadena aff. dea Fraser-Brunner, 1949, Torrente Stirone (IRSNB P 9742). L. Lampadena aff. speculigeroides Brzobohatý \& Nolf, 1996, Stazzano (IRSNB P 9743). M. Hygophum hygomii (Lütken, 1892), Mondovi, Madonna della Neve (IRSNB P 9744). N-O. Lampadena gracilis (Schubert, 1912); N. Alba, Tanaro (50 m), O. Mondovi, Madonna della Neve (IRSNB P 9745-P 9746). P-Q. Lobianchia gemellarii (Cocco, 1838), Sant'Alosio (IRSNB P 9747-P 9748). R. Hygophum derthonensis (Anfossi \& Mosna, 1969), Torrente Stirone (IRSNB P 9749). S-T. Lampanyctus latesulcatus Nolf \& Steurbaut, 1983, Sant'Agata Fossili (IRSNB P 9750-P 9751). U. Merluccius cf. merluccius (Linnaeus, 1758), Sant'Agata Fossili (IRSNB P 9752). V. Lobianchia dofleini (Zugmayer, 1911), Costa Vescovato (IRSNB P 9753). $1=$ ventral view; $2=$ inner view. Scale bars $=1 \mathrm{~mm}$. 
holotype of D. cahuzaci (refigured in Brzobohatý \& Nolf 2000: pl. 5, fig. 6) is more rounded if compared to the more elongate similar-sized (ca $2 \mathrm{~mm}$ ) lectotype of D. austriacus, which was established by Zilch (1965) (see Schwarzhans \& Aguilera 2013: pl. 10, fig. 1). The growth series of D. cahuzaci provided by Brzobohatý \& Nolf (2000: pl. 5, figs 1-6) clearly shows this consistent rounded outline feature and a stronger rostrum in the larger specimens that are different from the otoliths of $D$. austriacus figured by Schwarzhans \& Aguilera (2013: pl. 10, figs 1-8, the size of the largest specimen, fig. 7 is comparable to the one figured by Brzobohatý \& Nolf 2000: pl. 5, figs 4-5). Therefore, we interpret that D. cahuzaci is still a well-defined fossil species, and our Tortonian specimens (Fig. 5J) can be assigned to D. cahuzaci on the basis of the growth series illustrated by Brzobohatý \& Nolf (2000: pl. 5, figs 1-6).

The otoliths of D. cahuzaci resemble those of another species, Diaphus taaningi Norman, 1930 (see Brzobohatý \& Nolf 2000: pl. 2, figs 7-12 and pl. 5, figs 1-6, respectively); their small size further impedes an offhand distinction. Key features for distinguishing these species are the shape of the posterior and dorsal rims: these are both straight in D. taaningi but more curved in D. cahuzaci. On this basis, otoliths from Montaldo Torinese previously assigned to $D$. taaningi by Lin et al. $(2015$ : fig. 2(12, 13)) are here attributed to $D$. cahuzaci. It is also worth mentioning that the stratigraphic range of $D$. taaningi and D. cahuzaci in Brzobohatý \& Nolf (2000: fig. 2) has to be amended: D. taaningi is not represented in the Tortonian and the range of D. cahuzaci in the Serravallian is now shifted to the Tortonian since this record is based on material from the Tortonian deposits at Mondovi, Madonna della Neve, a locality that was incorrectly considered to be Serravallian at the time (see Locality data).

Genus Lampadena Goode \& Bean, 1893

Lampadena gracilis (Schubert, 1912)

The otoliths of $L$. gracilis are very rare at the investigated localities (Fig. $5 \mathrm{~N}-\mathrm{O}$ ). They are characterised by a more ventrally located sulcus, leaving a dorsal area that is wider than the ventral one, and by a prominent postero-dorsal angle. Their rostrum is directed straight anteriorly, and not upward, like in Lampadena dea Fraser-Brunner, 1949 (e.g., Fig. 5K). Recently, based only on otoliths, Schwarzhans (2013b: p. 160) erected a new fossil genus Paralampadena including three fossil species from West Africa as well as L. gracilis. However, following the diagnostic features described for Paralampadena, each criterion is covered by the high variability of extant Lampadena otoliths. For example, the statement that Paralampadena does not exhibit ventral denticles, a postero-dorsal depression, which can be rather deep and angular, thus reducing the posterior rim of the otolith to some extent, and the comparatively long cauda, can all be observed in the otoliths of Recent Lampadena anomala Parr, 1928, L. dea, L. notialis Nafpaktitis \& Paxton, 1968, and L. speculigera Goode \& Bean, 1896 (see Girone \& Nolf 2002 for the otolith iconography of all the Recent Lampadena species). Consequently, we retain that there is insufficient evidence for separating L. gracilis from the genus Lampadena.

Genus Lobianchia Gatti, 1904

The otoliths of Lobianchia gemellarii (Cocco, 1838) show an apparent ontogenetic variability (Fig. 6, Recent specimens). The small specimens of $L$. gemellarii are rather similar to those of the same-sized Lobianchia dofleini (Zugmayer, 1911), from which they differ in having a narrower sulcus and an obliquely inclining antero-dorsal rim that runs downwards to the antirostrum (Figs 5Q, 6 vs Nolf 2013: pl. 81). In large otoliths of $L$. gemellarii, the posterior rim becomes straight and the depression after the postero-dorsal angle is more pronounced (Figs 5P, 6). Otoliths of such a dimension (length about $8 \mathrm{~mm}$ ) are derived from fish attaining a length of about $11 \mathrm{~cm}$ (IRSNB collection), which is very huge compared to the average individual's maximum length of $6 \mathrm{~cm}$ (Nafpaktitis et al. 1977; Whitehead et al. 1986-1989). In the slope water off New England, Nafpaktitis et al. (1977) noted a number of specimens of $L$. gemellarii ranging in length between 85 and $100 \mathrm{~mm}$. Such large individuals are occasionally found 
outside the spawning area. Studies on comparative morphology of Recent Lobianchia otoliths have obtained similar results (Schwarzhans 2013a: pl. 15, figs 6, 7). Based on these observations, the studied material testifies to the occurrence of both species, L. dofleini (Fig. 5V) and L. gemellarii (Fig. 5P, Q), in the Tortonian sediments.

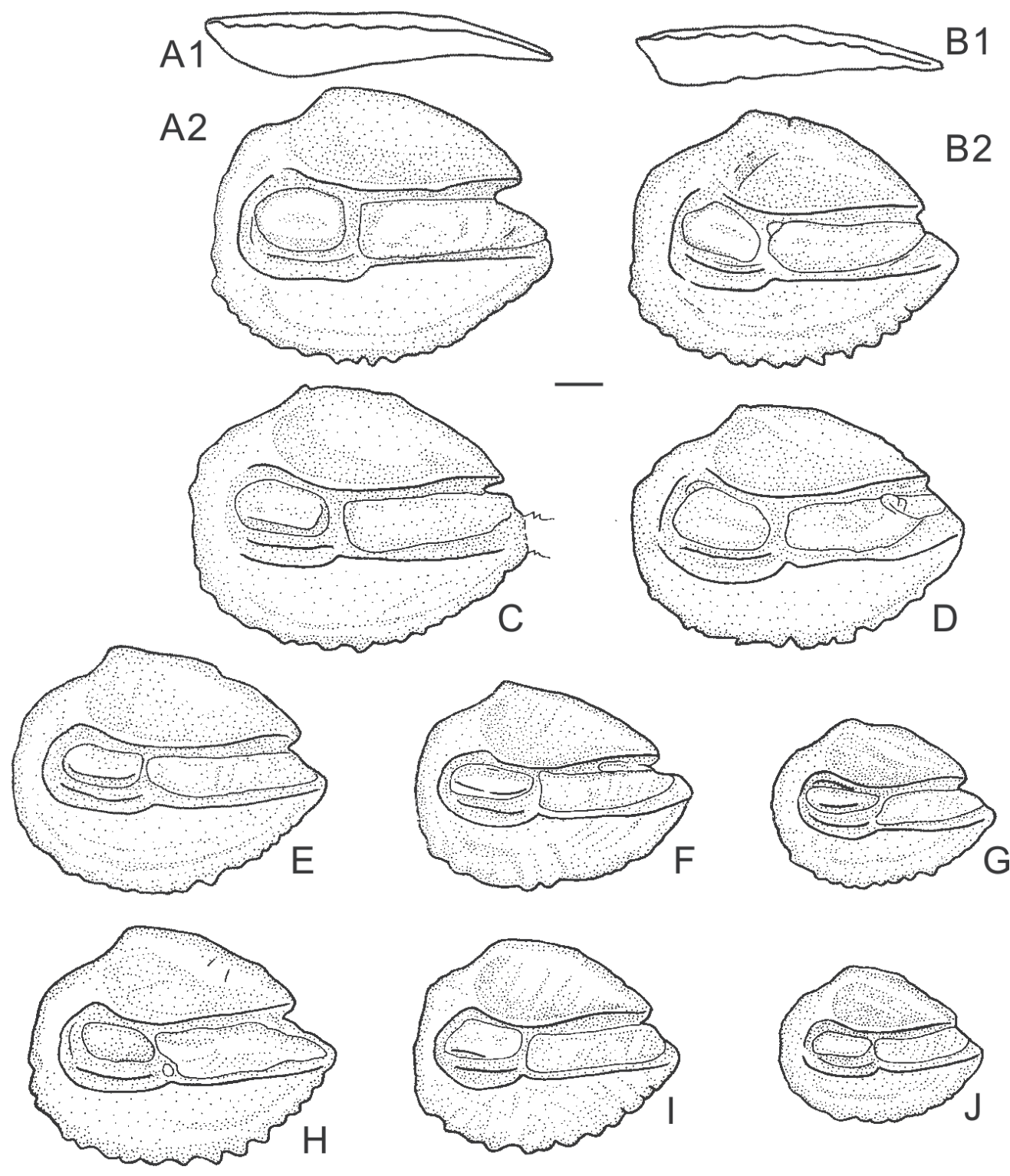

Fig. 6. Recent otoliths of Lobianchia gemellarii (Cocco, 1838). A, C, E-F, I. Strait of Messina, fish total length (TL) $9.0 \mathrm{~cm}, 9.0 \mathrm{~cm}, 8.1 \mathrm{~cm}, 7.0 \mathrm{~cm}$ and $7.0 \mathrm{~cm}$, respectively. B, D, G-H, J. Off Canaries, TL $9.0 \mathrm{~cm}, 9.0 \mathrm{~cm}, 4.8 \mathrm{~cm}, 9.0 \mathrm{~cm}$ and $4.8 \mathrm{~cm}$, respectively. $1=$ ventral view; $2=$ inner view. Scale bars $=$ $1 \mathrm{~mm}$. 


\section{Notoscopelus aff. caudispinosus (Johnson, 1863)}

A single, well-preserved otolith (Fig. 7I) is attributed, with some reserve, to the Recent Notoscopelus caudispinosus based on the shape of the dorsal rim that is the highest around the middle part of the otolith and on a posteriorly extended posterior part (see also Brzobohatý \& Nolf 1996: pl. 7, figs 8-9). This specimen, however, shows a general outline, similar to those of fossil Notoscopelus mediterraneus (Koken, 1891) and Symbolophorus meridionalis Steurbaut, 1979 (see Brzobohatý \& Nolf 1996: pl. 8, figs 1-15). Our specimen differs from those of $N$. mediterraneus by its more extended posterior rim, while otoliths of $S$. meridionalis show a flatter dorsal rim and a deeper incised excisura. A single specimen of Symbolophorus meridionalis, figured by Lin et al. (2015: fig. 3(7)), shows a much shorter outline, which suggests an attribution to the genus Myctophum Rafinesque, 1810 rather than to Symbolophorus Bolin \& Wisner, 1959, and, therefore, this attribution must be considered as doubtful.

Order Gadiformes Goodrich, 1909

Family Bregmacerotidae Gill, 1872

Genus Bregmaceros Thompson, 1840

\section{Bregmaceros sp.}

Bregmaceros Thompson, 1840 has small and thin otoliths which are easily recognised, but their identification at species level is problematic, because specific features mainly concern the overall shape of the outline and the protruding denticles, which are often not well-preserved in the fossil material. Therefore, the identification of fossil specimens in this group is delicate and requires sufficient specimens (Prrikryl et al. 2016). Our Bregmaceros otoliths (Fig. 7M-O) are characterised by a very large, wide and triangular antero-ventral lobe, and this key feature is different from that of Bregmaceros albyi (Sauvage, 1880), a more common species reported from the Tortonian of northern Italy (e.g., Anfossi \& Mosna 1969a, as Bregmaceros catulus). The shape of our Bregmaceros otoliths is actually more similar to that of Bregmaceros deklaszi Schwarzhans, 2013 (and Bregmaceros hybridus Schwarzhans, 2013, which may just reflect aspects of the variability of $B$. deklaszi, based on the iconographies) (see Schwarzhans 2013b: pl. 5, figs 19-26, 11-18, respectively), reported from the middle-late Miocene boundary of West Africa. But, again, the characteristic antero-ventral lobe of our specimens is still markedly larger than that of the West African species. In fact, these Tortonian otoliths do not match any of the currently known fossil species from the Mediterranean or Central Paratethys (Nolf 2013: pls 86-87; Přikryl et al. 2016), but, lacking sufficient material, we prefer to keep these specimens in open nomenclature.

Family Macrouridae Bonaparte, 1832

Genus Gadomus Regan, 1903

Gadomus tejkali (Brzobohatý \& Schultz, 1978)

“genus Melanonidarum” vanheuckelomae Nolf \& Steurbaut, 1983: pl. 4, figs 8-9.

The abundant occurrence of otoliths of G. tejkali at Mondovi allows a reconstruction of the otolith growth series of this species (Fig. 3E-L), in addition to the extensive growth series of the same species illustrated by Brzobohatý (1995: pl. 1, figs 1-11) from the Badenian (middle Miocene) of the Central Paratethys. The Tortonian and Badenian materials reveal that the specimens named "genus Melanonidarum" vanheuckelomae Nolf \& Steurbaut, 1983 are, in fact, the juvenile specimens of G. tejkali, and therefore "g. M." vanheuckelomae is synonymised here (see Nolf \& Steurbaut 1983 for iconography). 


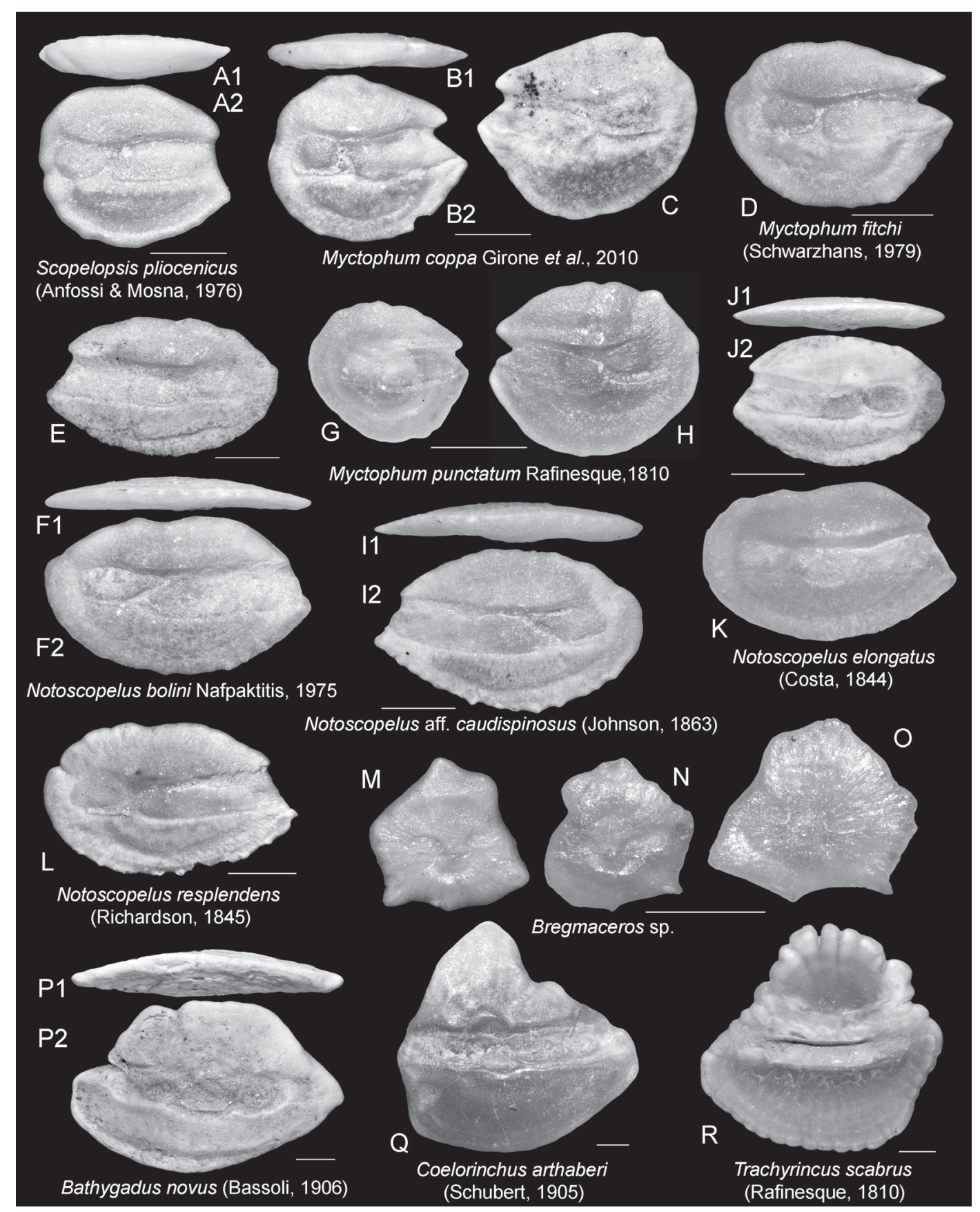

Fig. 7. Tortonian fish otoliths from northern Italy. A. Scopelopsis pliocenicus (Anfossi \& Mosna, 1976), Sant'Agata Fossili (IRSNB P 9754). B-C. Myctophum coppa Girone, Nolf \& Cavallo, 2010, Sant'Agata Fossili (IRSNB P 9755-P 9756). D. Myctophum fitchi (Schwarzhans, 1979), Torrente Stirone (IRSNB P 9757). E-F. Notoscopelus bolini Nafpaktitis, 1975, Torrente Stirone (IRSNB P 9760 P 9761). G-H. Myctophum punctatum Rafinesque,1810, Sant'Agata Fossili (IRSNB P 9758-P 9759). I. Notoscopelus aff. caudispinosus (Johnson, 1863), Mondovi, Madonna della Neve (IRSNB P 9764). J-K. Notoscopelus elongatus (Costa, 1844), Costa Vescovato (IRSNB P 9762-P 9763). L. Notoscopelus resplendens (Richardson, 1845), Gallo D'Alba (IRSNB P 9765). M-O. Bregmaceros sp., Sant'Agata Fossili (IRSNB P 9766-P 9768). P. Bathygadus novus (Bassoli, 1906), Sant'Agata Fossili (IRSNB P 9769). Q. Coelorinchus arthaberi (Schubert, 1905), Montegibbio (IRSNB P 9770). R. Trachyrincus scabrus (Rafinesque, 1810), Montegibbio (IRSNB P 9771). 1 = ventral view; 2 = inner view. Scale bars $=1 \mathrm{~mm}$. 
Genus Coelorinchus Giorna, 1809

Coelorinchus robustus (Robba, 1970)

The material of $C$. robustus known from the literature (Robba 1970: pl. 10, figs 4-6, pl. 11, figs 1-2; Nolf \& Steurbaut 1983: pl. 5, fig. 11; Brzobohatý 1995: pl. 2, figs 1-2; Lin et al. 2015: fig. 3(12)) as well as our material (Fig. 8L-M) all consist of huge adult otoliths. At a first glance, they resemble those of large Coelorinchus caelorhincus (Risso, 1810) (see Fig. 8A) a lot, but, apart from the extraordinary size of the specimens, the cauda is much longer in C.robustus, the posterior tip of the otolith is slightly directed upwards, and the collicula are wider and closer to each other at the collum, sometimes they are even fused together dorsally. One of the otoliths of C. caelorhincus figured by Lin et al. (2015: fig. 3(12)) exhibits the aforementioned features, suggesting much closer similarities to C. robustus than C. caelorhincus.

\title{
Genus Coryphaenoides Gunner, 1765
}

Coryphaenoides contortus (Bassoli, 1906)

The holotype of C. contortus was previously assigned to the genus Nezumia (Nolf \& Steurbaut 1983; Lin et al. 2015) based on the general outline of the otolith; however, the large, well-preserved specimen now available (Fig. 8B) shows a clear pince-nez-shaped sulcus with an upwardly bent crista superior and a crista inferior that is strongly constricted at the collum, suggesting closer affinities with the genus Coryphaenoides than with Nezumia Jordan, 1904.

Order Ophidiiformes Berg, 1937

Family Bythitidae Gill, 1861

Bythitidae indet.

These otoliths have a shorter, higher and thicker shape than those of typical slender and elongate Tortonian Grammonus bassolii (Nolf, 1980) (see Fig. 9H). Their features only suggest bythitid otoliths, which in most cases possess generalised characteristics such as an elliptic outline with an elliptical sulcus. In addition, it is not certain whether the larger and the smaller specimens belong to the same taxon (Fig. 9F and 9G, respectively).

\author{
Order Stephanoberycifirmes Berg, 1937 \\ Family Melamphaidae Gill, 1893 \\ Genus Scopelogadus Vaillant, 1888
}

\section{Scopelogadus sp.}

The larger otoliths (Fig. 9J and 9L) show some similarities with those of the Recent Scopelogadus (e.g., Scopelogadus beani (Günther, 1887) and Scopelogadus mizolepis (Günther, 1878), see Nolf 2013: pl. 161; Rivaton \& Bourret 1999: pl. 141, figs 11-20, respectively), but in the fossil specimens, the colliculum is much larger and wider, occupying nearly one-third of the inner face. A Scopelogadus otolith figured by Anfossi \& Mosna (1969b: pl. 10, fig. 8) from the Tortonian of northern Italy shows a similar sulcus with that of our specimens, but its outline configuration is more compressed and widened horizontally. Although ontogenetic change may also play a role, the existence of Anfossi \& Mosna's specimen and our smaller but thicker specimens (Fig. 9K) suggests that several as yet unrecognised species may be involved. 


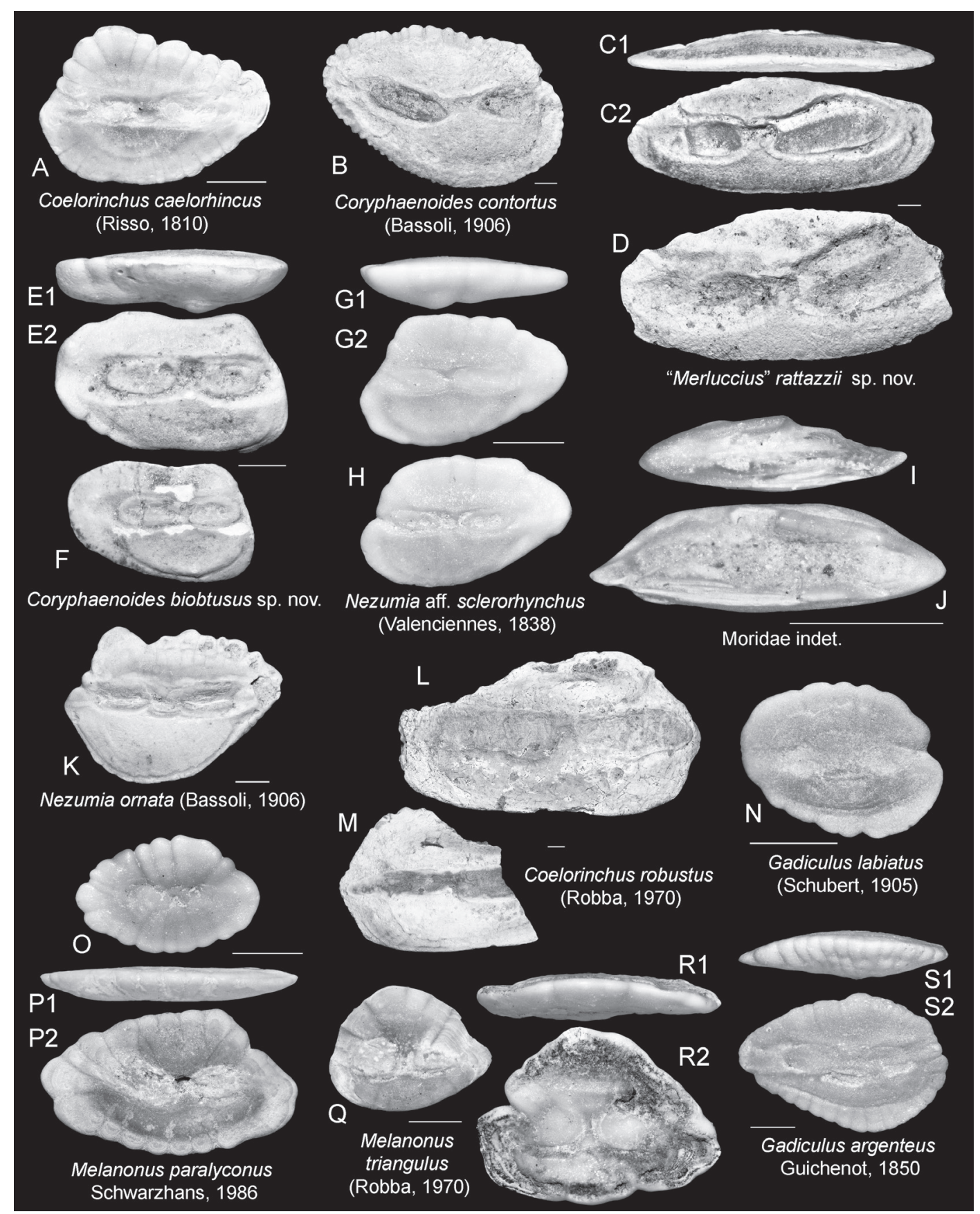

Fig. 8. Tortonian fish otoliths from northern Italy. A. Coelorinchus caelorhincus (Risso, 1810), Montegibbio (IRSNB P 9772). B. Coryphaenoides contortus (Bassoli, 1906), Sant'Alosio (IRSNB P 9773). C-D. "Merluccius" rattazzii sp. nov., Sant'Alosio (IRSNB P 9686 (holotype)-P 9687). E-F. Coryphaenoides biobtusus sp. nov., Alba, Tanaro (5 m) (IRSNB P 9684 (holotype)-P 9685). G-H. Nezumia aff. sclerorhynchus (Valenciennes, 1838), Alba, Tanaro (5 m) (IRSNB P 9774-P 9775). I-J. Moridae indet., Sant'Agata Fossili (IRSNB P 9776-P 9777). K. Nezumia ornata (Bassoli, 1906), Montegibbio (IRSNB P 9778). L-M. Coelorinchus robustus (Robba, 1970); L. Stazzano, M. Sant'Alosio (IRSNB P 9779-P 9780). N. Gadiculus labiatus (Schubert, 1905), Torrente Stirone (IRSNB P 9781). O-P. Melanonus paralyconus Schwarzhans, 1986, Mondovi, Madonna della Neve (IRSNB P 9782P 9783). Q-R. Melanonus triangulus (Robba, 1970), Costa Vescovato (IRSNB P 9784-P 9785). S. Gadiculus argenteus Guichenot, 1850, Torrente Stirone (IRSNB P 9786). 1 = ventral view; 2 = inner view. Scale bars $=1 \mathrm{~mm}$. 


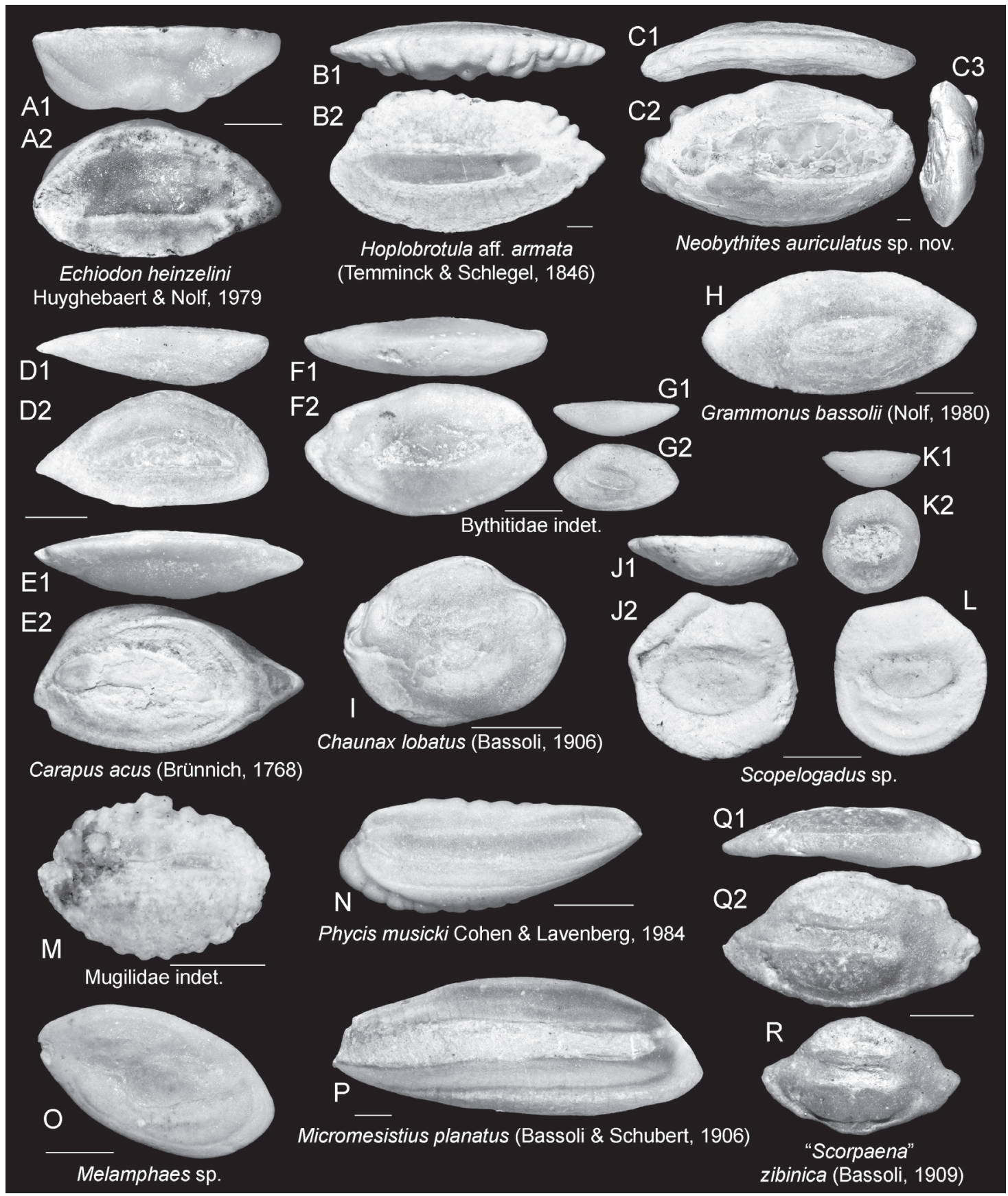

Fig. 9. Tortonian fish otoliths from northern Italy. A. Echiodon heinzelini Huyghebaert \& Nolf, 1979, Torrente Stirone (IRSNB P 9787). B. Hoplobrotula aff. armata (Temminck \& Schlegel, 1846), Sant'Alosio (IRSNB P 9788). C. Neobythites auriculatus sp. nov., Sant'Alosio (IRSNB P 9688 (holotype). D-E. Carapus acus (Brünnich, 1768); D. Torrente Stirone, E. Sant'Agata Fossili (IRSNB P 9789-P 9790). F-G. Bythitidae indet., Torrente Stirone (IRSNB P 9791-P 9792). H. Grammonus bassolii (Nolf, 1980), Torrente Stirone (IRSNB P 9793). I. Chaunax lobatus (Bassoli, 1906), Montegibbio (IRSNB P 9794). J-L. Scopelogadus sp.; J. Alba, Tanaro (5 m), K. Stazzano, L. Alba, Tanaro (50 m) (IRSNB P 9795-P 9797). M. Mugilidae indet., Sant'Alosio (IRSNB P 9798). N. Phycis musicki Cohen \& Lavenberg, 1984, Torrente Stirone (IRSNB P 9799). O. Melamphaes sp., Alba, Tanaro (50 m) (IRSNB P 9802). P. Micromesistius planatus (Bassoli \& Schubert, 1906), Montegibbio (IRSNB P 9803). Q-R. "Scorpaena" zibinica (Bassoli, 1909), Torrente Stirone (IRSNB P 9800-P 9801). 1 = ventral view; 2 = inner view; 3 $=$ anterior view. Scale bars $=1 \mathrm{~mm}$. 
Order Beryciformes Regan, 1909

Family Trachichthyidae Bleeker, 1859

Genus Hoplostethus Cuvier, 1829

\title{
Description
}

A large, adult otolith (Fig. 10F) of Hoplostethus lawleyi Koken, 1891 is easily distinguished from the Miocene Hoplostethus praemediterraneus Schubert, 1905 (Fig. 10A-E) by its very depressed anterodorsal area. This feature also characterises large-sized otoliths of the extant Hoplostethus mediterraneus Cuvier, 1829, but otoliths of $H$. lawleyi are different from those of $H$. mediterraneus in having a wider sulcus, a strongly developed ostial colliculum and a narrower ventral area. The distinction between $H$. mediterraneus and $H$. praemediterraneus can be made with the help of the growth series of H. praemediterraneus from the Badenian of the Carpathian Foredeep (Brzobohatý 1978: pl. 1, figs 1-16, as Hoplostethus levis biexcissus and H. l. levis) and of our material (Fig. 10A-E), which clearly demonstrate that the otoliths of $H$. praemediterraneus are, at each stage, higher and more compact in shape than those of H. mediterraneus (see Nolf 2013: pl. 165).

\author{
Order Perciformes Bleeker, 1859 \\ Family Gobiidae Cuvier, 1816 \\ Genus Deltentosteus Gill, 1863
}

\section{Deltentosteus sp.}

\section{Description}

Forty-four otoliths, here named Deltentosteus sp. (Fig. 11J-L), are very similar to those of Deltentosteus aff. quadrimaculatus (Valenciennes, 1837) from the Plio-Pleistocene deposits of Italy (Nolf \& Girone 2000: pl. 3, figs 5-12) and from our Tortonian material (Fig. 11D). The concerned 44 otoliths have a nearly flat inner face instead of the convex one of $D$. aff. quadrimaculatus, which makes them readily distinguishable. Consequently, although these otoliths could not yet be compared to Deltentosteus colonianus (Risso, 1826), a Recent Mediterranean species whose otoliths are currently not available, the occurrence of our Deltentosteus otoliths implies that another species could be involved.

Genus Gobius Linnaeus, 1758

“Gobius" bicornutus (Lin, Girone \& Nolf, 2015)

This species was described, for the first time, from the turbiditic Tortonian deposits in the open generic nomenclature as "Gobiida" bicornuta by Lin et al. (2015). Following the nomenclature adopted in the present paper and based on diagnostic features, this species is here assigned to "G." bicornutus (Lin, Girone \& Nolf, 2015). The otoliths of "G." bicornutus are rare in Tortonian deposits. They are very thick and nearly square shaped, with large and horn-like expansions at the postero-dorsal corner. Their sulcus is elliptic without strongly delimitated margins (Fig. 12A). Some small specimens (Fig. 12B-C) of this species from Sant'Agata Fossili (Nolf \& Steurbaut 1983: fig. 1.1, point C) also show the hornshaped expansion at the postero-dorsal corner, a feature which can be therefore considered as consistent, regardless of otolith size.

“Gobius" aff. weileri Bauza Rullan, 1955

This single thickset otolith is characterised by a rectangular shape and an elliptic sulcus, filled completely by an undivided colliculum (Fig. 11N). The sulcus margins are thick and swollen, and a slight constriction is observed at the middle of both anterior and posterior rims of the otolith. It is more similar to specimens 

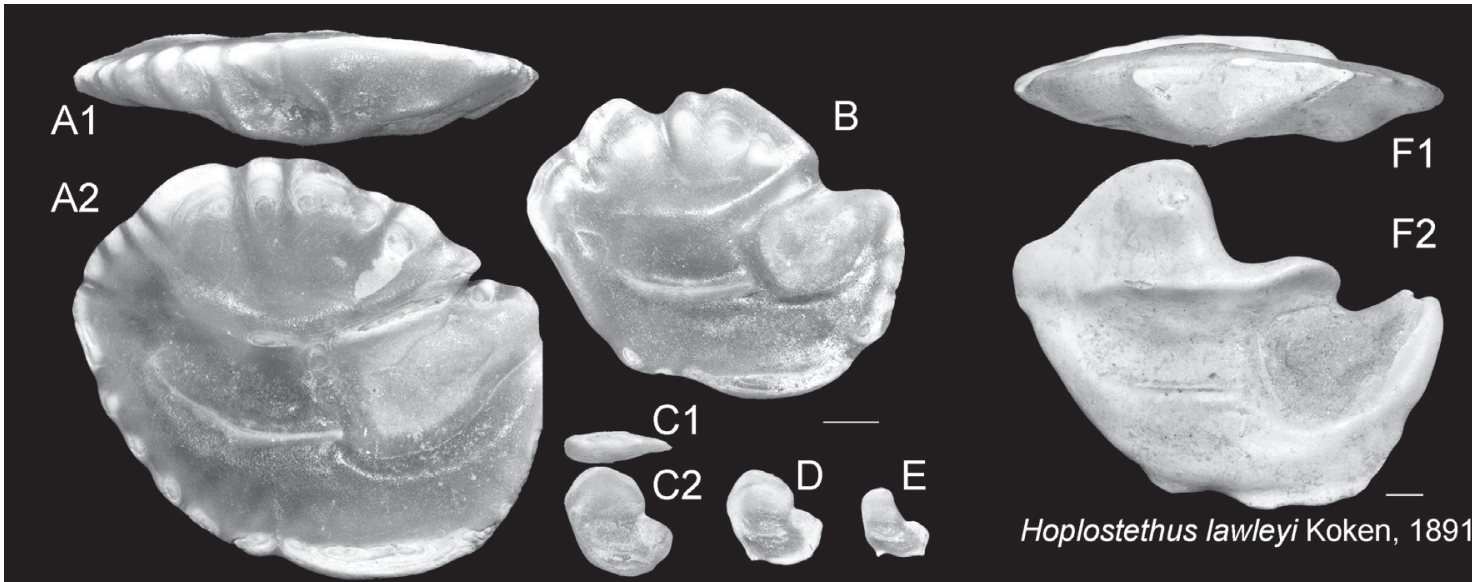

Hoplostethus praemediterraneus Schubert, 1905

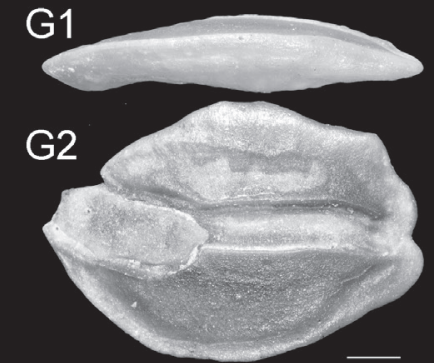

Parascombrops mutinensis (Bassoli, 1906)

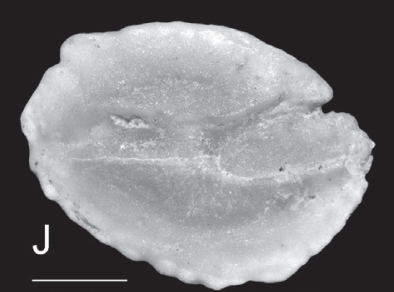

Epigonus constanciae (Giglioli, 1880)

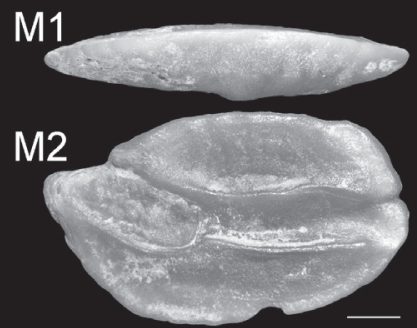

Epigonus italicus (Bassoli, 1906)
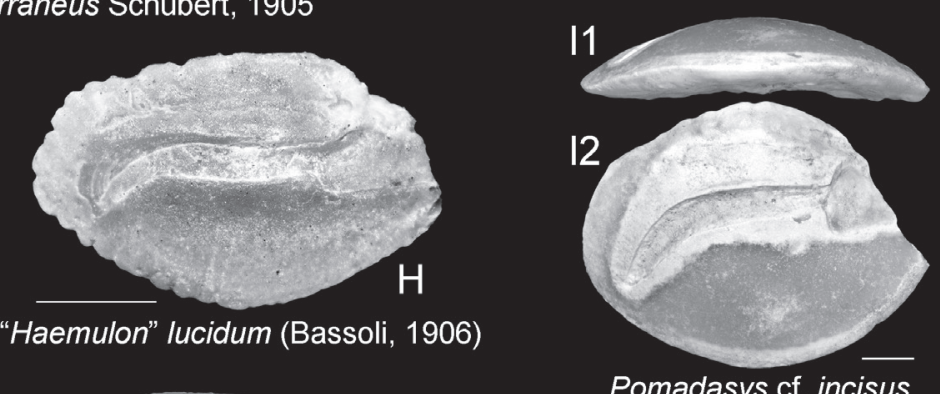

Pomadasys cf. incisus (Bowdich, 1825)
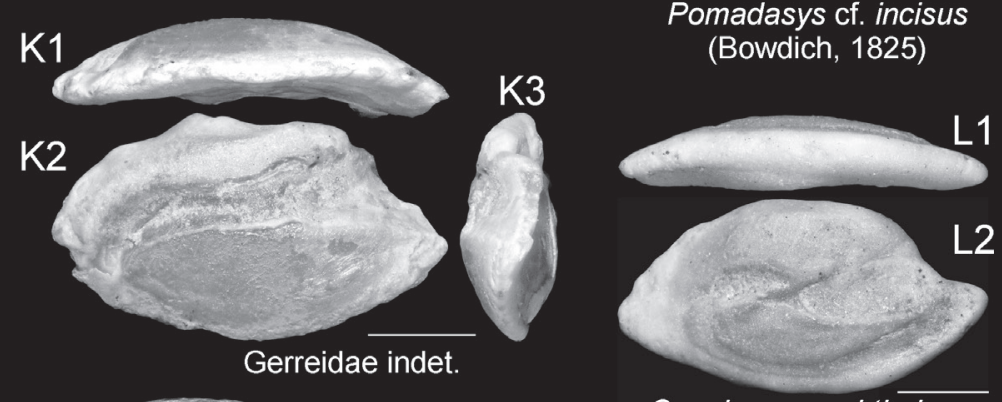

Cepola macrophthalma (Linnaeus, 1758)

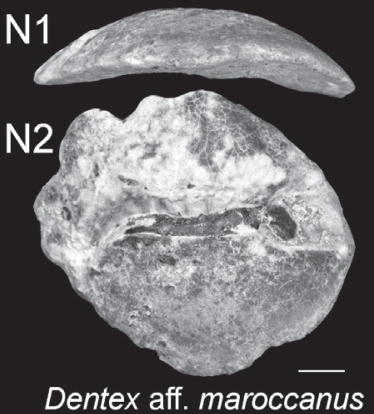

Dentex aff. maroccanus Valenciennes, 1830

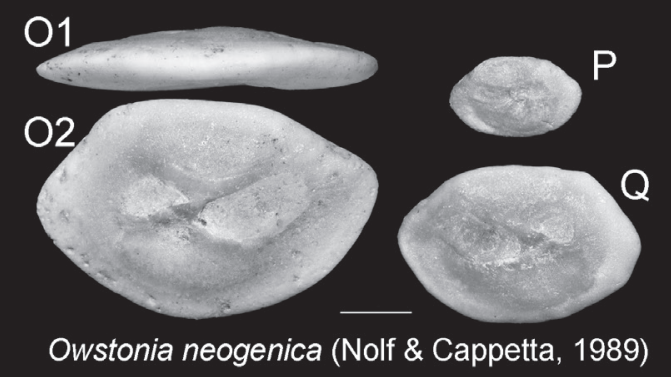

Fig. 10. Tortonian fish otoliths from northern Italy. A-E. Hoplostethus praemediterraneus Schubert, 1905; A-B. Montegibbio, C-E. Sant'Agata Fossili (IRSNB P 9804-P 9808). F. Hoplostethus lawleyi Koken, 1891, Sant'Agata Fossili (IRSNB P 9809). G. Parascombrops mutinensis (Bassoli, 1906), Torrente Stirone (IRSNB P 9810). H. "Haemulon" lucidum (Bassoli, 1906), Montegibbio (IRSNB P 9811). I. Pomadasys cf. incisus (Bowdich, 1825), Sant'Agata Fossili (IRSNB P 9812). J. Epigonus constanciae (Giglioli, 1880), Torrente Stirone(IRSNB P9813). K. Gerreidae indet., Montegibbio(IRSNB P 9814). L. Cepola macrophthalma (Linnaeus, 1758), Torrente Stirone (IRSNB P 9815). M. Epigonus italicus (Bassoli, 1906), Montegibbio (IRSNB P 9816). N. Dentex aff. maroccanus Valenciennes, 1830, Sant'Agata Fossili (IRSNB P 9817). O-Q. Owstonia neogenica (Nolf \& Cappetta, 1989), Torrente Stirone (IRSNB P 9818-P 9820). 1 = ventral view; 2 = inner view; 3 = anterior view. Scale bars $=1 \mathrm{~mm}$. 


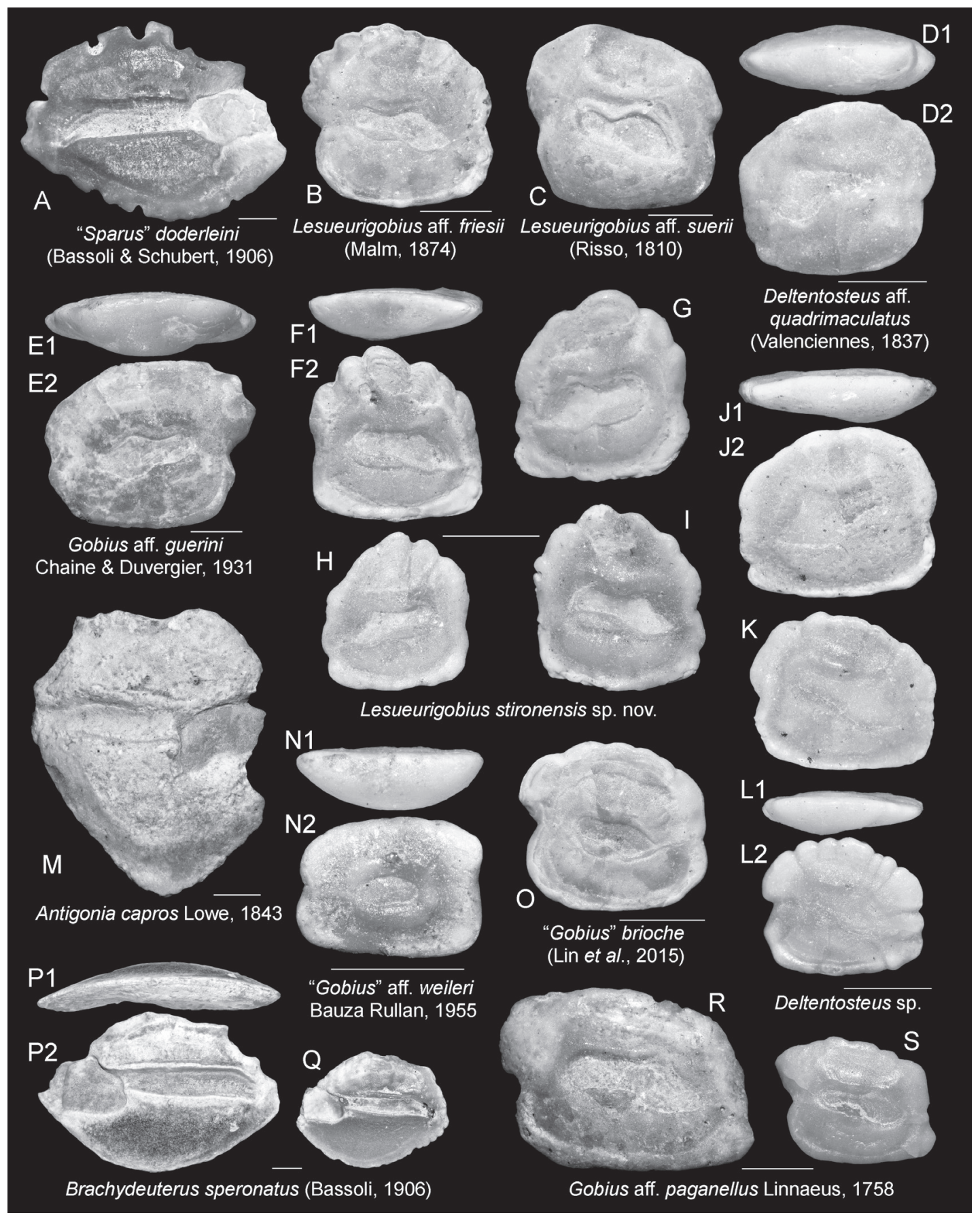

Fig. 11. Tortonian fish otoliths from northern Italy. A. "Sparus" doderleini (Bassoli \& Schubert, 1906), Sant'Agata Fossili (IRSNB P 9821). B. Lesueurigobius aff. friesii (Malm, 1874), Torrente Stirone (IRSNB P 9822). C. Lesueurigobius aff. suerii (Risso, 1810), Torrente Stirone (IRSNB P 9823). D. Deltentosteus aff. quadrimaculatus (Valenciennes, 1837), Torrente Stirone (IRSNB P 9824). E. Gobius aff. guerini Chaine \& Duvergier, 1931, Montegibbio (IRSNB P 9825). F-I. Lesueurigobius stironensis sp. nov., Torrente Stirone (IRSNB P 9689 (holotype)-P 9692). J-L. Deltentosteus sp., Torrente Stirone (IRSNB P 9826-P 9828). M. Antigonia capros Lowe, 1843, Montegibbio (IRSNB P 9829). N. "Gobius" aff. weileri Bauza Rullan, 1955, Torrente Stirone (IRSNB P 9830). O. "Gobius" brioche (Lin, Girone \& Nolf, 2015), Montegibbio (IRSNB P 9831). P-Q. Brachydeuterus speronatus (Bassoli, 1906), Montegibbio (IRSNB P 9832-P 9833). R-S. Gobius aff. paganellus Linnaeus, 1758; R. Torrente Stirone, S. Montegibbio (IRSNB P 9834-P 9835). 1 = ventral view; $2=$ inner view. Scale bars $=1 \mathrm{~mm}$. 
from the lower Pleistocene deposits of northern Italy figured by Nolf \& Girone (2000: pl. 3, figs 15-16) than to the one from the lower Pliocene deposit figured by Nolf \& Cavallo (1995: pl. 8, fig. 10), but the thickness of our specimen resembles more the latter.

\section{Gobiidae indet.}

These small otoliths have a high and large dorsal area, which is occupied by a wide dorsal depression; the sulcus is shallow and poorly delimitated (Fig. 12H-I). They are grouped together according to their similar morphological features, but it cannot be excluded that more than one species is represented here because of their small dimension, which precludes an unequivocal identification.

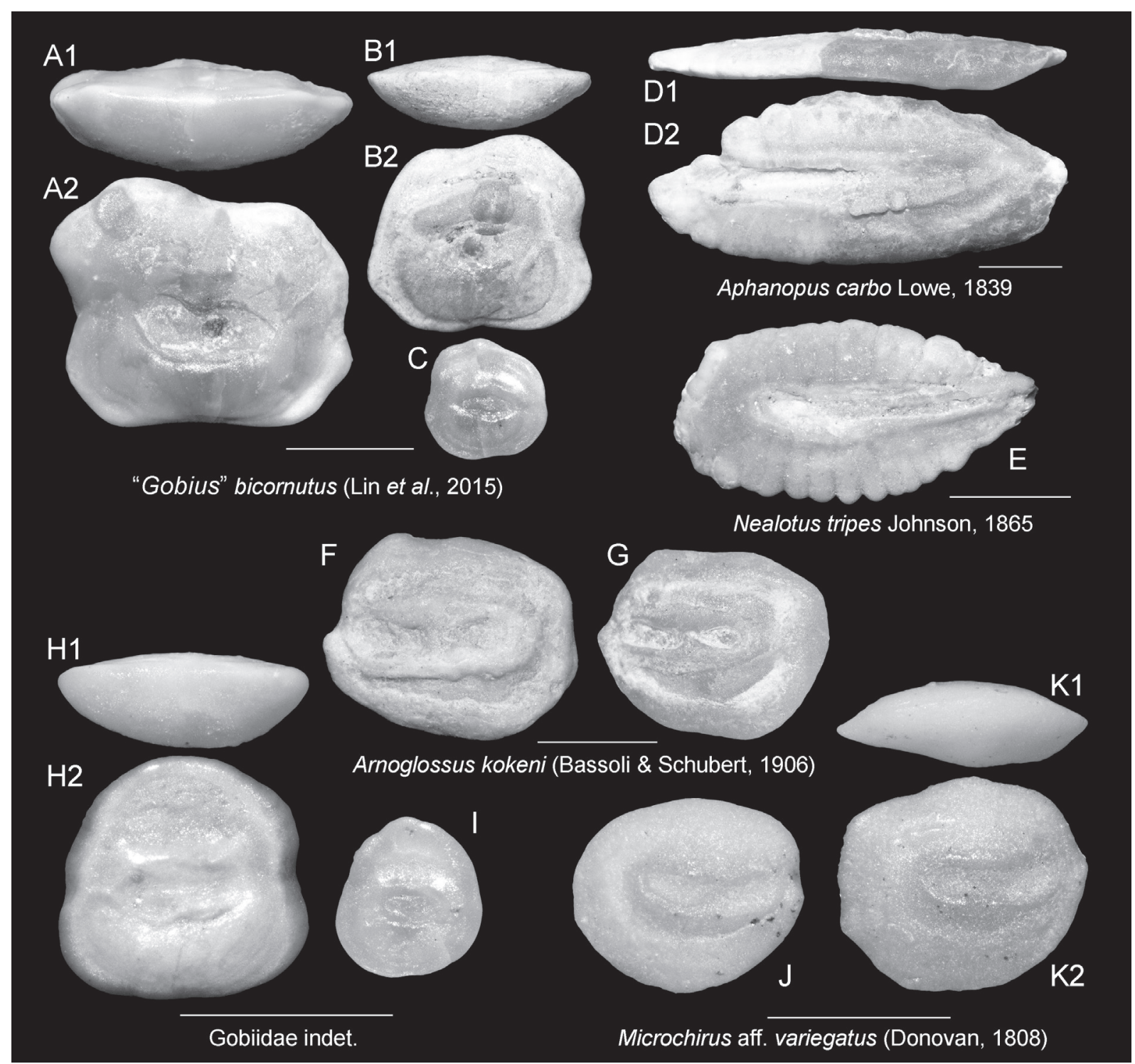

Fig. 12. Tortonian fish otoliths from northern Italy. A-C. "Gobius" bicornutus (Lin, Girone \& Nolf, 2015), Sant'Agata Fossili (IRSNB P 9836-P 9838). D. Aphanopus carbo Lowe, 1839, Costa Vescovato (IRSNB P 9839). E. Nealotus tripes Johnson, 1865, Mondovi, Madonna della Neve (IRSNB P 9840). F-G. Arnoglossus kokeni (Bassoli \& Schubert, 1906), Torrente Stirone (IRSNB P 9841-P 9842). H-I. Gobiidae indet., Sant'Agata Fossili (IRSNB P 9843-P 9844). J-K. Microchirus aff. variegatus (Donovan, 1808), Torrente Stirone (IRSNB P 9845-9846). 1 = ventral view; 2 = inner view. Scale bars $=1 \mathrm{~mm}$. 
Family Gempylidae Gill, 1862

Genus Nealotus Johnson, 1865

Nealotus tripes Johnson, 1865

An otolith, named Prometichthys prometheus by Lin et al. (2015: fig. 7(1)), is also assigned to N. tripes: three additional specimens from Mondovi (one figured on Fig. 12E) present a very similar spindle shape, and seem to be nearest to those of the Recent $N$. tripes (see Nolf 2013: pl. 327). The otoliths of $P$. prometheus (Cuvier, 1832) also show a reasonable resemblance, but the sulcus is straighter in $N$. tripes, and the rostrum in P. prometheus is more prominent with a conspicuous excisura notch.

\section{An overview on the taxonomic composition of investigated localities}

A list of taxa recognised in this study is given in Table 1 (page 6 and following), with all of them illustrated by at least one specimen. The present study, based on more than 5600 otoliths, reveals the presence of at least 109 taxa belonging to 38 families. Of these, 88 taxa were identified at species level. Among all the investigated localities, Sant'Agata Fossili and Montegibbio are the most diversified at family level, consisting of 20 and 18 families, respectively. The most abundant material came from Mondovi, Madonna della Neve, where more than 1600 specimens were collected. Furthermore, this locality is also characterised by many true oceanic mesopelagic taxa, such as microstomatids, sternoptychids and phosichthyids. At the Torrente Stirone locality, the otolith assemblage is most diversified at species level (51 taxa), of which the most abundant and even dominant taxa are neritic gobiids and congrids. Finally, the assemblages recognised at the Alba, Tanaro, Costa Vescovato, Gallo D'Alba, Sant'Alosio, and Stazzano localities show the typical characteristics of deep-water taxa, with a near-absence of neritic elements.

\section{Discussion}

\section{A synthesis of the nominal species and an evaluation on their stratigraphic and geographic distribution}

A list of the nominal species from the Tortonian of Northern Italy with updated revisions by Nolf (2013) and the present study is compiled in Table 2. Several additional Tortonian otolith specimens deposited at the Museo Geologico, University of Torino, Italy (MGUT) are also included: Pterothrissus umbonatus (MGUT 11529), Pseudophichthys splendens (MGUT 11563), Coelorinchus maximus (MGUT 11575), Pycnocraspedum cetonaense (MGUT 11557), Hoplostethus lawleyi (MGUT 11541, 11551), Hoplostethus praemediterraneus (MGUT 11555), Holocentrus weileri (MGUT 11575), Argyrosomus regius (MGUT 11540), Owstonia neogenica (MGUT 11563). For the source of other stratigraphic data, see below.

The otolith-based Tortonian fauna of the Mediterranean contains 118 nominal species (Table 2), with a considerably high proportion that can be assigned to modern genera (108 out of 118 , ca $91.5 \%$ ). It is clear that, from the taxonomic point of view, the late Miocene teleostean fauna of the Mediterranean shows a close affinity with that of the present day, at least at the generic level. Seventeen (living and extinct) species are recorded as fossils for the first time in the Tortonian deposits. A rather high number of 21 fossil species (18\%) have a stratigraphic range apparently confined to the upper Miocene (Tortonian and early Messinian, see Table 2) of the Mediterranean realm.

Fifty-three out of 118 species (45\%) are regarded as Recent species known as fossil; 14 of those belong to the family Myctophidae, and the remaining 39 represent 27 families. Most of these Recent species have a continuous fossil record in younger Mediterranean strata and they have a modern Atlantic and/ 
or Mediterranean geographic distribution, which implies that the Tortonian Mediterranean fauna has a closer affinity with the Recent Atlantic-Mediterranean fauna than with the Recent Indo-Pacific one.

\section{Placing of the Tortonian otolith association from northern Italy in time and space}

In this section we intend to study the Tortonian otolith association with regard to data on otoliths from older and younger deposits in the Paleomediterranean realm and in adjacent geographic areas: the Central Paratethys and the Eastern Atlantic-Lusitanian realms (Table 3). In the Mediterranean realm, otoliths have been recorded from Bartonian deposits to the present day. Important Paleogene and Miocene otolith assemblages are mainly from various localities in northern Italy (Table 3). Outside the Mediterranean realm, there are also many data on otoliths from the Central Paratethys, while in the Eastern Atlantic realm, the Aquitaine Basin (SW France) is the best documented succession of otolith assemblages of the whole world from the Ypresian to the Serravallian. Additional otoliths are documented from the Serravallian and Piacenzian deposits of Portugal (Table 3). In the Eastern Paratethys, relevant work has recently been published by Bratishko et al. (2015) on the middle Miocene (early Serravallian) otolith associations, showing a high degree of autonomy.

It is not our aim to provide here a synthesis of the vast amount of data cited above, a very pertinent observation of Nolf \& Brzobohatý (1994) was that the $60 \%$ of the nominal Chattian species recorded from the Eger area (Hungary, Central Paratethys) is also known from the Chattian of Aquitaine. This demonstrates that, notwithstanding our incomplete knowledge of Mediterranan Chattian otoliths, a faunal continuity and similarity over the vast Paratethys-Mediterranean-Aquitaine area, at least in the deep neritic facies, can be implied. With this in mind, we can state that from the Priabonian to Recent, we have for the Mediterranean and adjacent areas, a reasonably well-established overview of the teleost fish faunas, as reconstructed by otoliths. In many cases, the lacunas (gaps) in one area are compensated by data from adjacent ones, e.g., the complete lack of data for the Mediterranean Chattian is compensated by the good knowledge of contemporaneous faunas in the Central Paratethys and Aquitaine, the rather poor data for the Mediterranean Langhian are also compensated by good data from the Central Paratethys and Aquitaine, and the very poor data for the Mediterranean Serravallian are compensated by good data from Aquitaine and Portugal, albeit only from the neritic environment, and not the oceanic one. The Tortonian fauna is very well documented in the Mediterranean, as are those of the later Pre-evaporitic Messinian, the Pliocene, and the Pleistocene.

Our final discussion will focus on a comparison with faunas of the deep neritic and upper slope facies, as a comparison with the very neritic associations (e.g., those from the Rupelian of Aquitaine or from the lower Miocene of Southern France) would only demonstrate the facies-related differences between them. The post-Langhian faunas of the Central Paratethys (Sarmatian, Pannonian and Pontian, see Brzobohatý \& Stancu 1974; Brzobohatý \& Pana 1985) are also too neritic and too endemic for a useful comparison. The relevant deposits to compare with are:

1. The Rupelian of Eastern Piemonte, Italy (Nolf \& Steurbaut 2004, the most bathyal otolith association presently known) and the association from the Pouzdřany Formation, Central Paratethys (Brzobohatý \& Krhovský 1998):

Of the 118 nominal Tortonian species, six (5.1\%), namely Bathycongrus nagymarosyi (Nolf \& Brzobohatý, 1994), Bathygadus novus (Bassoli, 1906), Coelorinchus cristatus (Bassoli, 1906), Nezumia ornata (Bassoli, 1906), Melanonus triangulus (Robba, 1970) and Hoplobrotula acutangula (Koken, 1884), are also recorded from the deep-water Rupelian of northern Italy, and only a single species, M. triangulus, is documented from the Pouzdřany Marl (Table 2, Fig. 13). The Rupelian faunas share very few species with our Tortonian fauna. Except for M. triangulus, a possible mesopelagic species as inferred from its modern relatives, all others are strikingly demersal fish inhabiting the continental slope environment. 


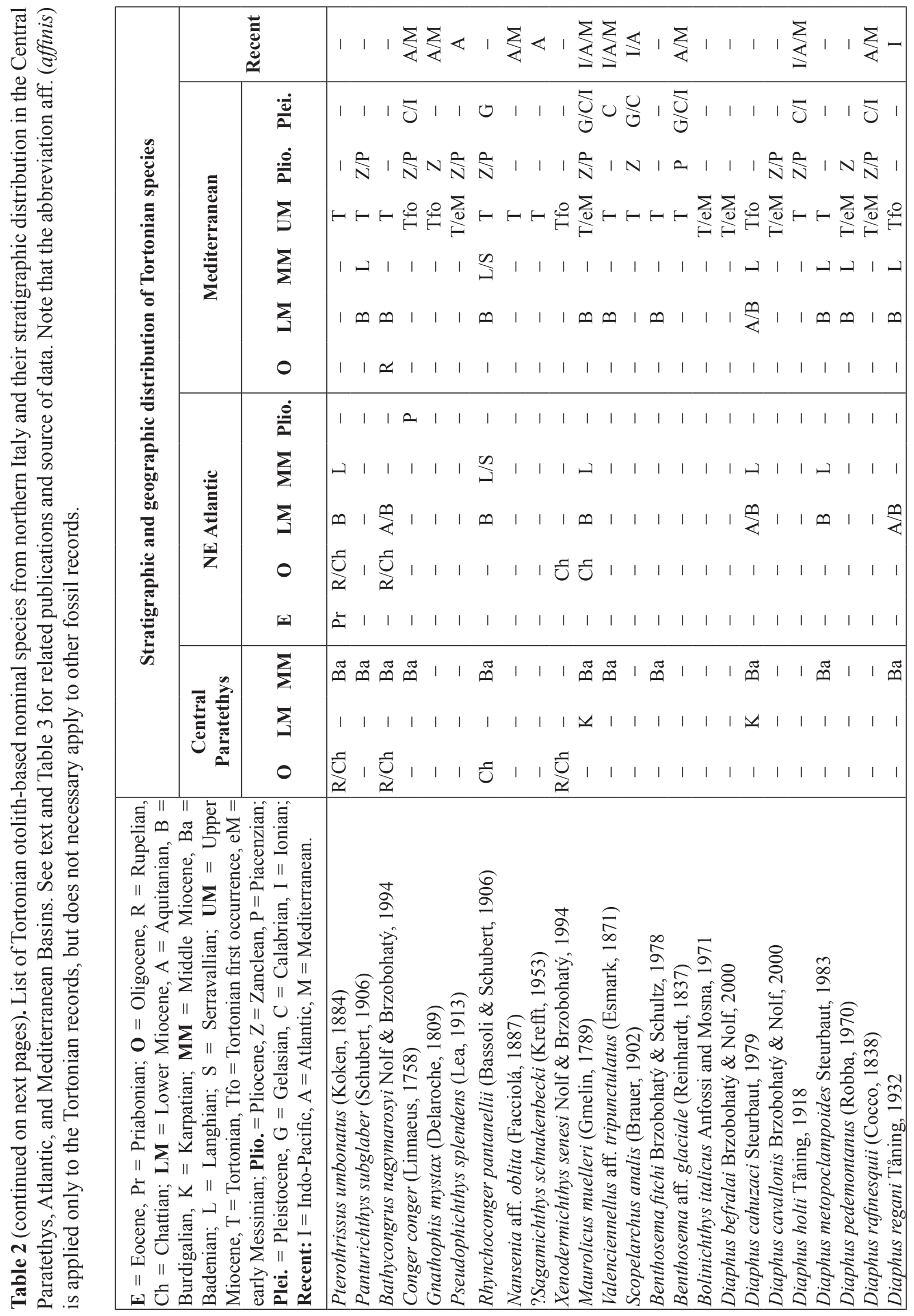




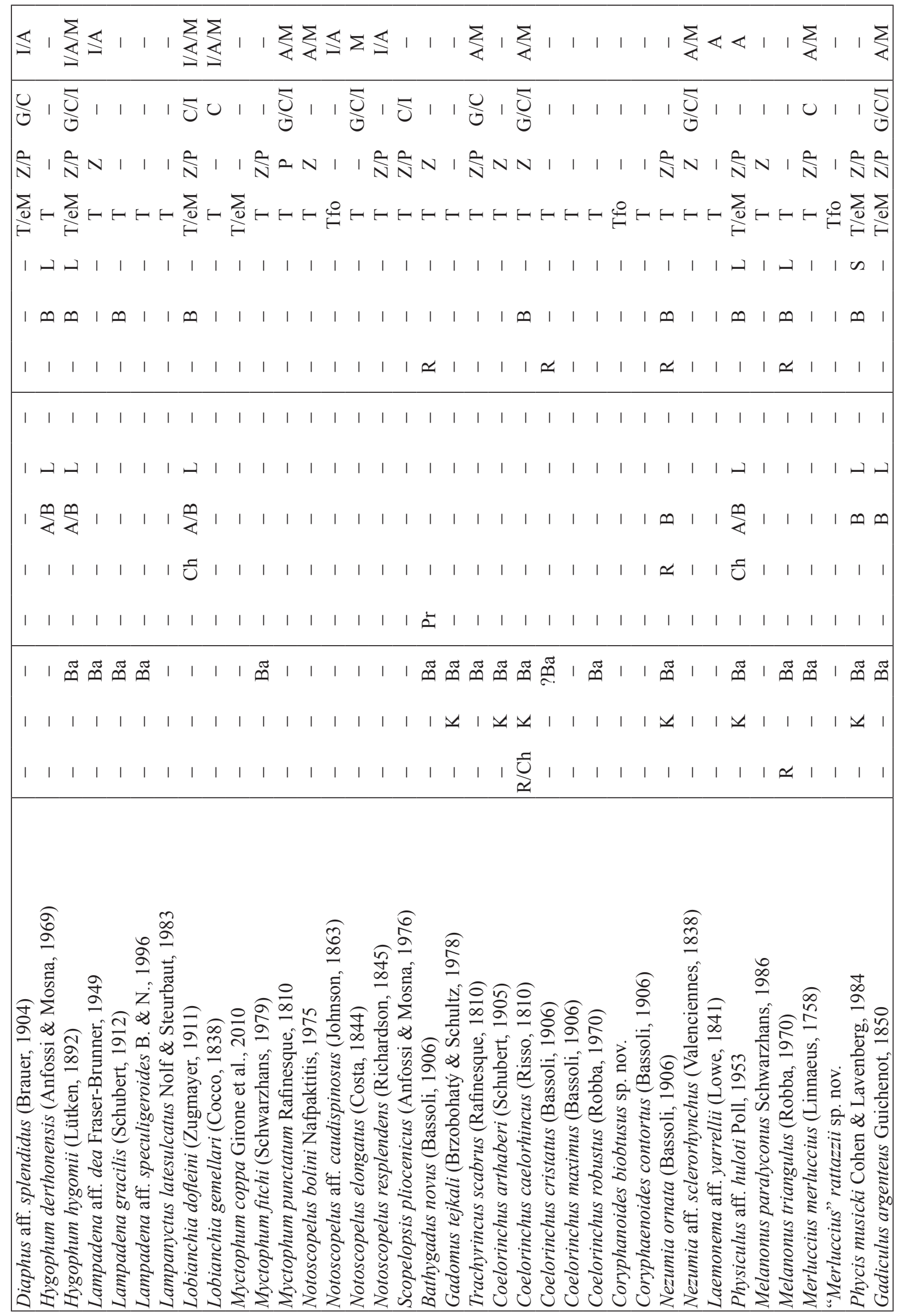




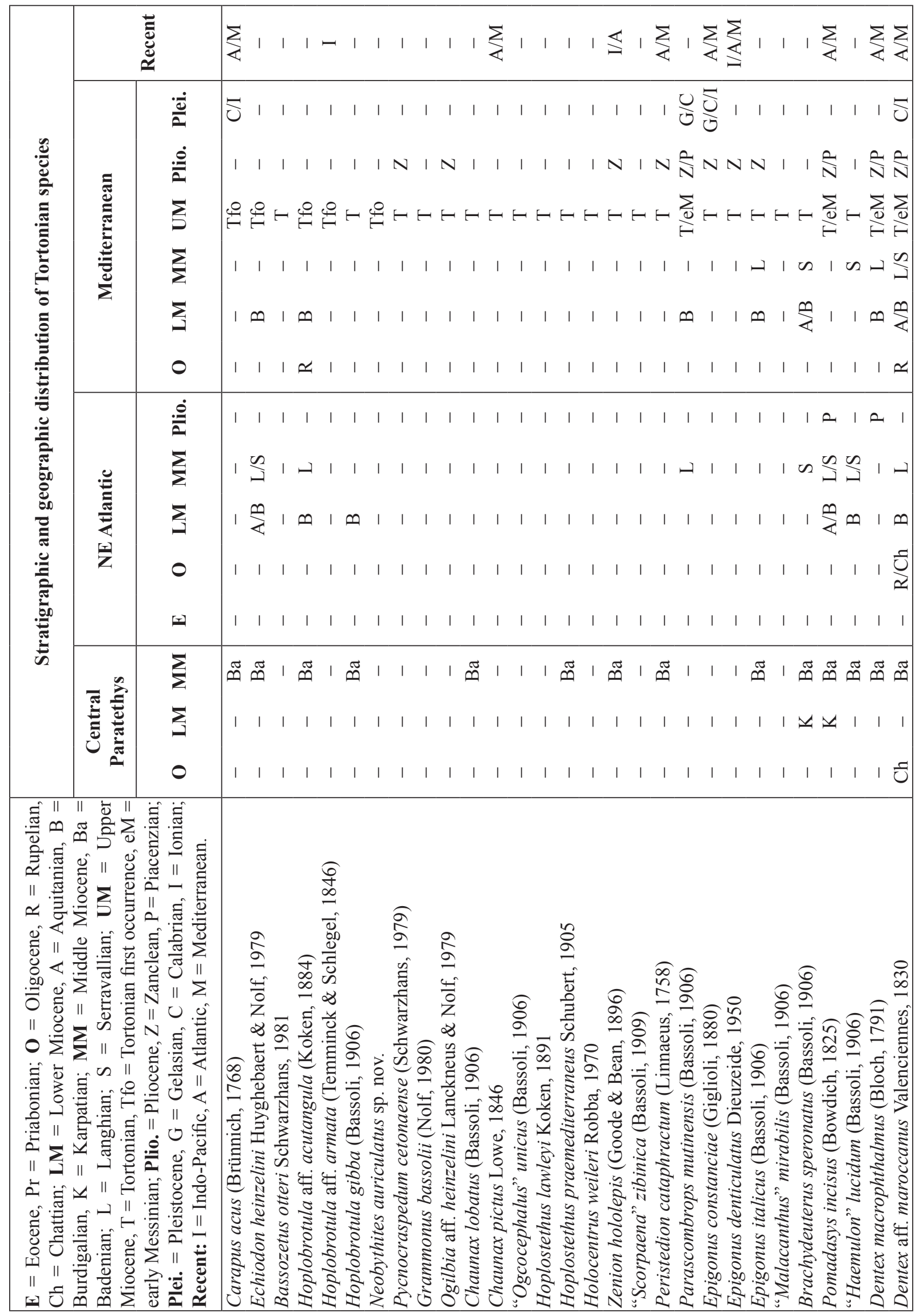




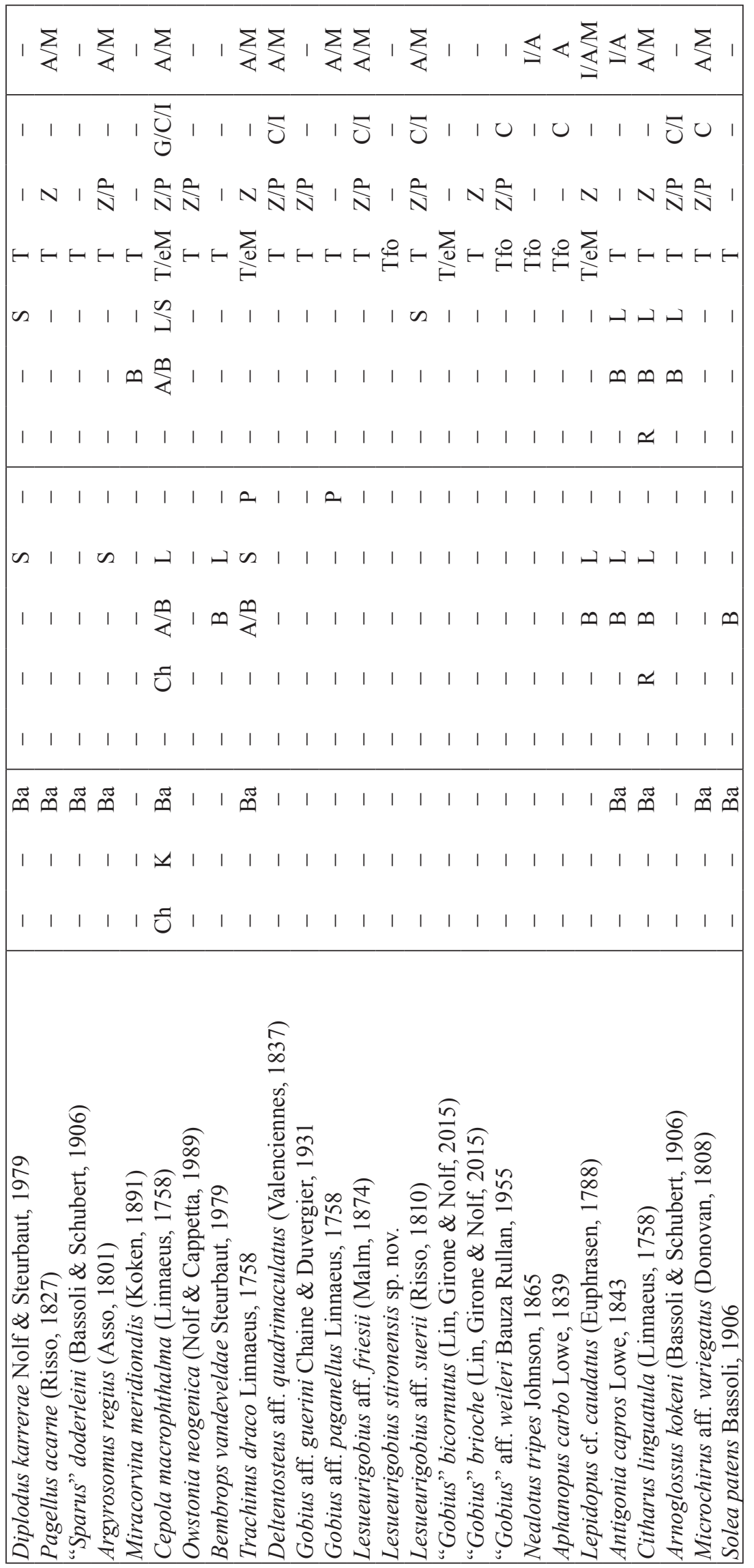


Table 3. Important otolith assemblages and studies from the Eocene to Pleistocene in the Mediterranean Area, the Central Paratethys and the NE Atlantic.

\begin{tabular}{|c|c|c|c|c|}
\hline \multicolumn{2}{|c|}{ Chronostratigraphy } & Mediterranean & Central Paratethys & NE Atlantic \\
\hline & Pleistocene & $\begin{array}{l}\text { mainly S Italy, neritic to deep-water } \\
\text { (97 taxa) Girone } \text { et al. } 2006\end{array}$ & \multirow[b]{2}{*}{ no data } & no data \\
\hline & Pliocene & $\begin{array}{c}\text { various localities (ca } 145 \text { taxa) } \\
\text { SE France: Nolf \& Cappetta } 1989 \\
\text { N Italy: Nolf \& Girone 2006; Girone } 2007 \\
\text { Spain: Nolf et al. } 1998\end{array}$ & & $\begin{array}{c}\text { Vale de Freixo (Portugual), } \\
\text { neritic (20 taxa) } \\
\text { Nolf \& Marques da Silva } \\
1997\end{array}$ \\
\hline \multirow{2}{*}{ 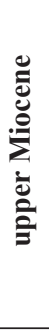 } & Messinian & $\begin{array}{l}\text { N Italy, neritic (97 taxa) } \\
\text { Girone et al. } 2010 \\
\text { Tuscany (N Italy), brackish } \\
\text { Caputo et al. } 2009\end{array}$ & \multirow{2}{*}{$\begin{array}{c}\text { neritic and endemic, } \\
\text { Brzobohatý \& Pana } 1985 \\
\text { Brzobohatý \& Stancu } 1974\end{array}$} & \multirow{2}{*}{ no data } \\
\hline & Tortonian & $\begin{array}{l}\text { N Italy, deep-water (65 taxa) } \\
\text { Nolf \& Steurbaut } 1983 \\
\\
\text { Borelli (N Italy), turbiditic } \\
\text { (90 taxa) Lin et al. } 2015\end{array}$ & & \\
\hline \multirow[b]{2}{*}{ 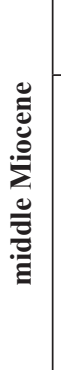 } & Serravallian & $\begin{array}{l}\text { S Turkey, neritic (47 taxa) } \\
\text { Schwarzhans } 2014\end{array}$ & \multirow{3}{*}{$\begin{array}{c}\text { various localities (Badenian), } \\
\text { neritic to deep-water } \\
\text { (ca 150 taxa) } \\
\text { Brzobohatý \& Schultz } 1978 \\
\text { Radwańska } 1992 \\
\text { Brzobohaty } 1994 \\
\text { Brzobohatý et al. } 2007 \\
\text { Nolf \& Brzobohatý } 2009 \\
\text { Schwarzhans et al. } 2015\end{array}$} & \multirow{6}{*}{$\begin{array}{c}\text { Paleocanyon of Saubrigues } \\
\text { Marl (Aquitaine, SW France) } \\
\text { Chattian-Langhian, } \\
\text { deep-water } \\
\text { Nolf \& Brzobohaty } 2002 \\
\\
\text { Aquitaine (SW France), } \\
\text { Rupelian, nearshore } \\
\text { Nolf \& Steurbaut } 2002 \\
\text { Portugal, Serravallian } \\
\text { (60 taxa) } \\
\text { Steurbaut \& Jonet } 1982\end{array}$} \\
\hline & Langhian & $\begin{array}{l}\text { Piemonte (N Italy), deep-water } \\
\text { (20 taxa) Steurbaut } 1983 \\
\text { Old otolith collection from the hills of } \\
\text { Torino (N Italy) in the MGUT }\end{array}$ & & \\
\hline \multicolumn{2}{|c|}{$\begin{array}{c}\text { Burdigalian/ } \\
\text { Langhian boundary }\end{array}$} & $\begin{array}{l}\text { Catalunya (Spain) (60 taxa) } \\
\text { Hoedemakers \& Batllori } 2005\end{array}$ & & \\
\hline 这 & $\begin{array}{c}\text { Burdigalian } \\
\text { Aquitanian }\end{array}$ & $\begin{array}{c}\text { Piemonte (N Italy), } \\
\text { deep-water (77 taxa) } \\
\text { Nolf \& Brzobohatý } 2004 \\
\\
\text { Montperyroux (France), neritic } \\
\text { Nolf \& Cappetta } 1980 \\
\\
\text { La Paillade (S France), neritic } \\
\text { Reichenbacher \& Cappetta } 1999\end{array}$ & $\begin{array}{l}\text { Karpatian: various localities, } \\
\text { neritic to deep-water ( } 49 \text { taxa) } \\
\text { Brzobohatý et al. } 2003 \\
\text { Ottnangian: no relevant data } \\
\text { from marine facies }\end{array}$ & \\
\hline \multirow{2}{*}{ 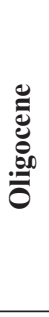 } & Chattian & no data & $\begin{array}{l}\text { Kiscellian and Egerian (NE } \\
\text { Hungary), deep-water ( } 52 \text { taxa) } \\
\text { Nolf \& Brzobohatý } 1994\end{array}$ & \\
\hline & Rupelian & $\begin{array}{c}\text { Castellane (SE France), neritic (38 taxa) } \\
\text { Nolf \& Girone } 2008 \\
\text { Piemonte (N Italy), deep-water (70 taxa) } \\
\text { Nolf \& Steurbaut } 2004 \\
\end{array}$ & $\begin{array}{c}\text { Pouzdřany Formation, } \\
\text { deep water (44 taxa) } \\
\text { Brzobohatý \& Krhovský } 1998\end{array}$ & \\
\hline \multirow{4}{*}{ 节 } & Priabonian & $\begin{array}{l}\text { Possagno (N Italy) and Allons } \\
\text { (SE France), neritic to deep-water } \\
\text { (55 taxa) Girone \& Nolf } 2009\end{array}$ & \multirow{4}{*}{ no relevant data } & \multirow{4}{*}{$\begin{array}{c}\text { Aquitaine (SW France), } \\
\text { Ypresian-Priabonian, deep } \\
\text { neritic (143 taxa) Nolf } 1988 \\
\text { Aquitaine (SW France), } \\
\text { Lutetian, deep neritic ( } 89 \text { taxa) } \\
\text { Lin et al. } 2016\end{array}$} \\
\hline & Bartonian & $\begin{array}{c}\text { Ronca (N Italy), brackish water } \\
\text { (1 species) } \\
\text { Nolf \& Reichenbacher } 1999\end{array}$ & & \\
\hline & Lutetian & \multirow{2}{*}{ no data } & & \\
\hline & Ypresian & & & \\
\hline
\end{tabular}


2. The Rupelian/Chattian of Hungary, Central Paratethys (Nolf \& Brzobohatý 1994) and the Chattian (Saint-Etienne-d'Orthe Clay) filling of the Saubrigues paleocanyon, Aquitaine (Nolf \& Brzobohatý 2002):

Eight Tortonian species $(6.7 \%)$ have also been recorded in both the Rupelian/Chattian of Hungary and the Chattian of the paleocanyon at Saubrigues (Table 2, Fig. 13). As is the case for the Rupelian deposits, the number of species in common is still very low, but five of these occur in both deposits; this relatively high number suggests an open connection between the two basins (Nolf \& Brzobohaty 1994). It is noteworthy that not only deep demersal and mesopelagic taxa are documented, but also neritic elements (Dentex aff. maroccanus Valenciennes, 1830 and Cepola macrophthalma (Linnaeus, 1758)) have been recorded in these rather deep deposits.

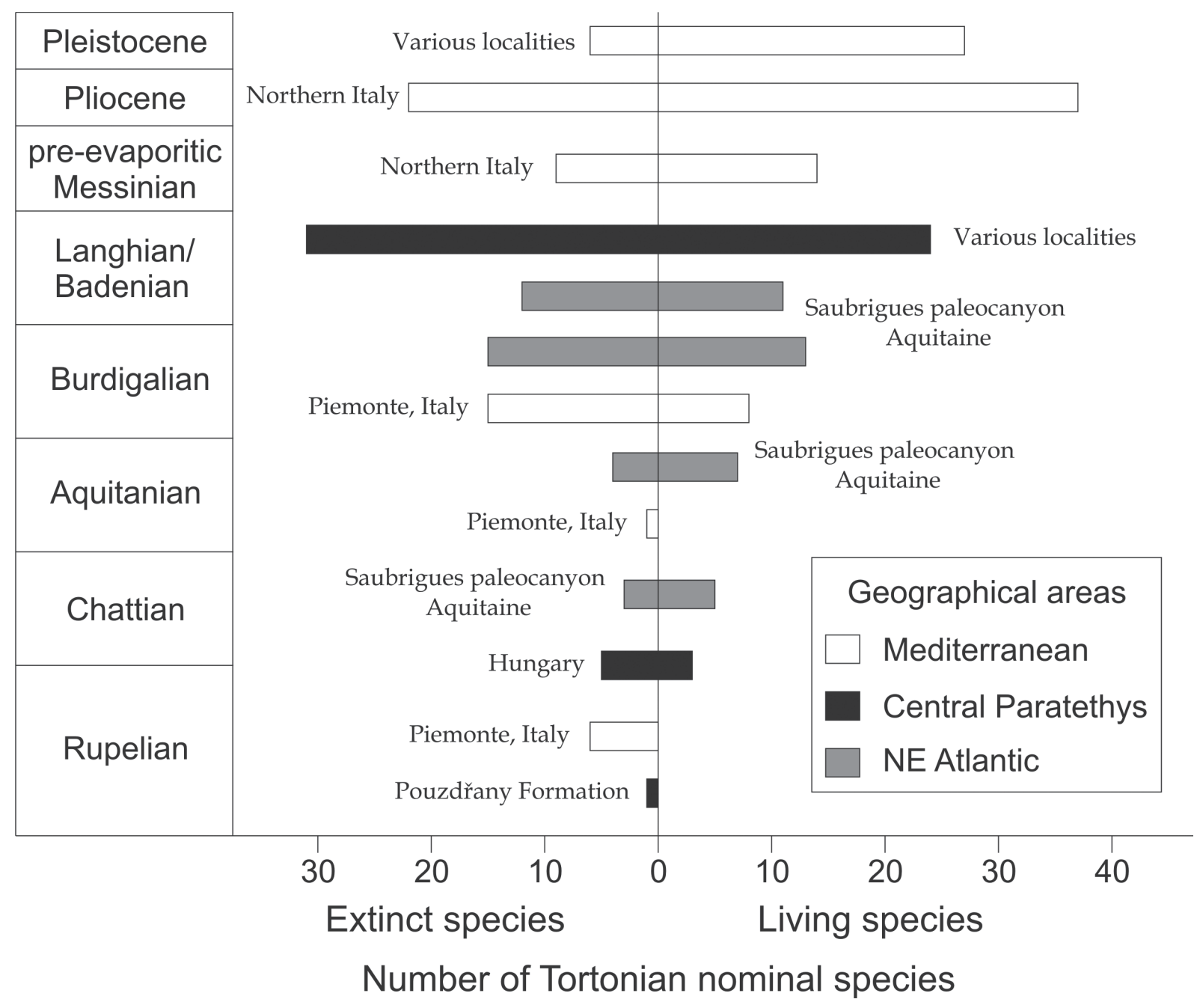

Fig. 13. Placement of the Tortonian otolith-based fauna in time and space. Number of the Tortonian nominal species shared by various otolith assemblages is indicated separately in extinct and living species. Note that the investigated otolith assemblages within each geological time interval (Series/ Stage) are not placed choronologically. 
3. The Aquitanian and Burdigalian of Piemonte, northern Italy (Nolf \& Brzobohatý 2004) and of the Saubrigues Marl, Aquitaine (Nolf \& Brzobohatý 2002):

In northern Italy, only a single Tortonian species (Diaphus cahuzaci) is also documented from the Aquitanian locality, whereas 23 deep-water species (19.5\%) are found in the Burdigalian (Table 2, Fig. 13). On the other hand, the Tortonian shares 11 (9.3\%) and 28 species (23.7\%) with the Aquitanian and Burdigalian deposits of the Saubrigues Marl in the Aquitaine Basin, respectively (Table 2, Fig. 13). Notwithstanding the discrepancy in the Aquitanian record for the Italian and Aquitaine faunas, the number of shared species in the Burdigalian is considerable and 16 species are in common for both faunas. In comparison with the Oligocene faunas (see above), these lower Miocene faunas are represented by a wider spectrum of taxa belonging to more than 15 families, and also by a few Recent species that make their first appearance as fossils. Obviously, in the early Miocene, a fundamental faunal turnover occurred in the studied part of the Paleomediterranean realm and adjacent areas, with the appearance of taxa characteristic of the later Tortonian fauna (Nolf \& Brzobohatý 2002).

4. The Badenian (middle Miocene) of the Central Paratethys (Brzobohatý \& Schultz 1978; Radwańska 1992; Brzobohatý 1994; Brzobohatý et al. 2007; Nolf \& Brzobohatý 2009) and the Langhian of the Saubrigues Marl, Aquitaine (Nolf \& Brzobohatý 2002):

The Badenian fauna of the Central Paratethys shares 55 species (46.6\%) with the Tortonian from the Mediterranean, whereas the latter one shares only 23 species (19.5\%) with the Langhian of the Aquitaine Basin (Table 2, Fig. 13). In fact, the condition of the Langhian fauna of the Aquitaine Basin is very similar to what has been observed in the lower Miocene faunas of the same basin, where a close affinity with the Tortonian fauna is not evident. The Badenian otolith-based teleost fauna, on the contrary, is one of the faunas that shows the closest affinity with our Tortonian fauna, and among the 55 species in common, 24 (43.6\%) are Recent species known as fossils. This implies that, although fossil species still play a major role, the growing number of the modern forms becomes evident from the middle Miocene onwards, at least in the Central Paratethys.

\section{The pre-evaporitic Messinian of northern Italy (Girone et al. 2010):}

A comparison with the pre-evaporitic Messinian otolith-based teleost fauna reveals that only 23 species are in common with the Tortonian one (Table 2, Fig. 13). Although these are represented by deepwater mesopelagic and even neritic species belonging to a rather wide variety of 13 families, the deep demersal elements such as the macrourids are completely absent. Several of the Tortonian macrourids and other deep demersal elements are still documented in the younger Pliocene strata, but many others apparently became extinct after the Tortonian stage (Table 2, Fig. 13). This indicates that perhaps at the early stage of the Messinian Salinity Crisis, the deep demersal fish were the first to receive the impact, and, subsequently, suffered heavily.

\section{The Pliocene (Nolf \& Girone 2006) and Pleistocene (Girone et al. 2006) faunas of northern Italy:}

The Pliocene and Tortonian teleost faunas of the Mediterranean have the highest number of species in common, 59 (50.0\%) in total (Table 2, Fig. 13). The Badenian of the Central Paratethys has a comparable number of species in common with the Tortonian (see above), but the Pliocene fauna contains markably more Recent species known as fossils (37 out of 59, 62.7\%) than the former (Fig. 13). Furthermore, all of these Recent species have a modern Atlantic and/or Mediterranean distribution. The restoration of the Mediterranean fauna after the Salinity Crisis must have been rapid, in view of the high number of common species found again in the Pliocene deposits. It also tells us that eventually the ancient Tortonian species were replaced by extant ones from the Atlantic realm. Such inference is also supported by the fact that a lower number of 33 Tortonian species $(28.0 \%)$ has been reported in the Pleistocene deposits (Table 2, Fig. 13), indicating that gradually more and more fossil species became extinct. 
In summary, on the basis of the otolith record, one can state that the Tortonian fauna of the Mediterranean is on the one hand most similar to that of the Badenian of the Central Paratethys in that they share many extinct Miocene species, but on the other hand, our Tortonian fauna is also very close to that of the Pliocene of the Mediterranean, by having many modern Atlantic-Mediterranean forms in common (Fig. 13). Consequently, the Tortonian otolith association of the Mediterranean is unique in having a mixture of extinct and extant species, in combination with several species apparently confined to the upper Miocene.

\section{Acknowledgements}

It is a pleasure for us to thank Bruno Rattazzi, Henri Cappetta, Oreste Cavallo, Etienne Steurbaut, Giulio Pavia, Elio Robba and Robert Marquet, who provided part of the material. We are very grateful to Erica Bicchi (Laboratoire de Géologie, Université d'Angers, France), Erlend Martini (Kronberg im Taunus), Donata Violanti (Dipartimento di Scienze della Terra, Università degli Studi di Torino, Italy) and to Patrizia Mariorano (Dipartimento di Scienze della Terra e Geoambientali, Università degli Studi di Bari Aldo Moro, Italy) for their help on biostratigraphic analyses. Oreste Cavallo and Pierre Hoffman assisted in the field work. This manuscript has been clearly improved by the revisions of Kristiaan Hoedemakers and Bettina Reichenbacher. Chien-Hsiang Lin was financially supported by the Ministry of Education, Taiwan, under "government scholarship for overseas study" during his Ph.D. program. The microscope laboratory at the Dipartimento di Scienze della Terra and Geoambientali, University of Bari Aldo Moro, was funded by Potenziamento Strutturale PONa3_00369 "Laboratorio per lo Sviluppo Integrato delle Scienze e delle Tecnologie dei Materiali Avanzati e per dispositivi innovativi (SISTEMA)".

\section{References}

Anfossi G. \& Mosna S. 1969a. Otoliti del bacino terziario Ligure-Piemontese (Tortoniano e Miocene superiore). Atti dell'Istituto geologico della Università di Pavia 20: 23-49.

Anfossi G. \& Mosna S. 1969b. Ulteriori contributi allo studio degli otoliti del bacino terziario LigurePiemontese. Atti dell'Istituto geologico della Università di Pavia 20: 57-66.

Anfossi G. \& Mosna S. 1971. Alcuni otoliti del Miocene medio-superiore Tortonese. Atti dell'Istituto geologico della Università di Pavia 21: 138-147.

Bassoli G.G. 1906. Otoliti fossili terziari dell'Emilia. Rivista Italiana di Paleontologia 12: 36-61.

Bratishko A., Schwarzhans W., Reichenbacher B., Vernyhorova Y. \& Ćorić S. 2015. Fish otoliths from the Konkian (Miocene, early Serravallian) of Mangyshlak (Kazakhstan): testimony to an early endemic evolution in the Eastern Paratethys. Paläontologische Zeitschrift 89 (4): 839-889. https://doi. org/10.1007/s12542-015-0274-4

Brzobohatý R. 1978. Zur ontogenetischen Entwicklung der fossilen Hoplostethiden (Otolithen, Miozän). Acta Musei Moraviae, Scientiae Naturales 63: 49-56.

Brzobohatý R. 1994. Die Fischotolithen des Badenien von Gainfarn, Niederösterreich (Mittelmiozän, Wiener Becken). Annalen des Naturhistorischen Museums Wien 96A: 67-93.

Brzobohatý R. 1995. Macrouridae (Teleostei, Otolithen) im Oligozän und Miozän der Zentralen Paratethys und ihre paläogeographische Bedeutung. Jahrbuch der Geologischen Bundesanstalt, Wien 138 (4): 615-637.

Brzobohatý R. \& Krhovský J. 1998. A synopsis of the teleost taxa from the Pouzdrany Formation (West Carpathians, Pouzdrany Unit, Early Oligocene). Zemni Plyn a Nafta 43 (2): 279-289.

Brzobohatý R. \& Nolf D. 1996. Otolithes de myctophidés (poissons téléostéens) des terrains tertiaires d'Europe: révision des genres Benthosema, Hygophum, Lampadena, Notoscopelus et Symbolophorus. Bulletin de l'Institut royal des Sciences naturelles de Belgique, Sciences de la Terre 66: 151-176. 
Brzobohatý R. \& Nolf D. 2000. Diaphus otoliths from the European Neogene (Myctophidae, Teleostei). Bulletin de l'Institut royal des Sciences naturelles de Belgique, Sciences de la Terre 70: 185-206.

Brzobohatý R. \& Nolf D. 2002. Stomiiformes (Teleostei, Otolithen) aus dem Miozän der Karpatischen Vortiefe (Westkarpaten, Mähren) und der Zentralen Paratethys insgesamt. Courier Forschungsinstitut Senckenberg 237: 139-150.

Brzobohatý R. \& Pana I. 1985. Die Fischfauna des Pannonien. In: Papp A., Jambor A. \& Steininger F. (eds) M6 Pannonien (Slavonien und Serbien), Chronostratigraphie und Neostratotypen. Miozän der zentralen Paratethys 7: 426-439.

Brzobohatý R. \& Schultz O. 1978. Die Fischfauna des Badeniens. In: Papp A., Cicha I., Senes J. \& Steininger F. (eds) M4 Badenien (Moravien, Wielicien, Kosovien), Chronostratigraphie und Neostratotypen. Miozän der zentralen Paratethys 6: 441-465.

Brzobohatý R. \& Stancu J. 1974. Die Fischfauna des Sarmatien. In: Papp A., Marinescu F. \& Senes J. (eds) M5 Sarmatien, Die sarmatische Schichtengruppe und ihr Stratotypus, Chronostratigraphie und Neostratotypen. Miozän der zentralen Paratethys 4: 492-515.

Brzobohatý R., Reichenbacher B. \& Gregorova R. 2003. Teleostei (Otoliths, Skeletons with otoliths in situ) from the Karpatian of the Central Paratethys. In: Brzobohatý R., Cicha I., Kovac M. \& Rögl F. (eds) The Karpatian, a Lower Miocene stage of the Central Paratethys: 265-279. Masaryk University, Brno.

Brzobohatý R., Nolf D. \& Kroupa O. 2007. Fish otoliths from the Middle Miocene of Kienberg at Mikulov, Czech Republic, Vienna Basin: Their paleoenvironmental and paleogeographic significance. Bulletin de l'Institut royal des Sciences naturelles de Belgique, Sciences de la Terre 77: 167-196.

Caputo D., Carnevale G. \& Landini W. 2009. Fish otoliths from the Messinian of Strada degli Archi (Tuscany, Italy) - taxonomy and palaeoecology. Annalen des Naturhistorischen Museums Wien 111: 257-280.

Fornaciari E., Di Stefano A., Rio D. \& Negri A. 1996. Middle Miocene quantitative calcareous nannofossil biostratigraphy in the Mediterranean region. Micropaleontology 42 (1): 1-36. https://doi. org $/ 10.2307 / 1485982$

Gaudant J., Cavallo O., Courme-Rault M.-D., Fornaciari E., Lauriat-Rage A., Lapparent F. \& Merle D. 2007. Paléontologie des marnes Tortoniennes affleurant dans le lit du Tanaro, près d'Alba (Piémont, Italie). Rivista Piemontese di Storia Naturale 28: 3-51.

Gaudant J., Cavallo O., Courme-Rault M.-D., Fornaciari E. \& Lauriat-Rage A. 2008. Paléontologie du gisement de poissons fossiles du Messinien préévaporitique de Roddi, près d'Alba (Piémont, Italie). Rivista Piemontese di Storia Naturale 29: 3-60.

Girone A. 2007. Piacenzian otolith assemblages from northern Italy (Rio Merli section, Emilia Romagna). Bollettino della Società Paleontologica Italiana 45 (2-3): 159-170.

Girone A. \& Nolf D. 2002. Lampadena ionica: a new teleost from the Mediterranean Pleistocene. Rivista Italiana di Paleontologia e Stratigrafia 108 (3): 493-500.

Girone A. \& Nolf D. 2009. Fish otoliths from the Priabonian (Late Eocene) of North Italy and SouthEast France - Their palaeobiogeographical significance. Revue de Micropaléontologie 52: 195-218. https://doi.org/10.1016/j.revmic.2007.10.006

Girone A., Nolf D. \& Cappetta H. 2006. Pleistocene fish otoliths from the Mediterranean Basin: a synthesis. Geobios 39: 651-671. https://doi.org/10.1016/j.geobios.2005.05.004

Girone A., Nolf D. \& Cavallo O. 2010. Fish otoliths from the pre-evaporitic (Early Messinian) sediments of northern Italy: their stratigraphic and palaeobiogeographic significance. Facies 56: 399-432. https:// doi.org/10.1007/s10347-010-0212-6 
Hoedemakers K. \& Batllori J. 2005. Fish otoliths from the Early and Middle Miocene of the Penedès (Catalunya, Spain). Batalleria 12: 105-134.

Hoedemakers K. \& Schneider S. 2016. Fish otoliths from the Rupelian (Early Oligocene) of Bad Freienwalde (NE Germany). Paläontologische Zeitschrift 90: 125-144. https://doi.org/10.1007/s12542015-0278-0

Iaccarino S. 1985. Mediterranean Miocene and Pliocene planktic foraminifera. In: Bolli H.M., Saunders J.B. \& Perch-Nielsen K. (eds) Plankton Stratigraphy 1: 283-314. Cambridge University Press, Cambridge.

Lin C.-H. 2016. Fish otolith assemblages in Recent sea bottoms and in ancient (Eocene and Miocene) fossiliferous deposits: a comparative study of taxonomy and paleoecology. Unpublished $\mathrm{PhD}$ thesis. Università degli Studi di Bari Aldo Moro, Bari, Italy.

Lin C.-H. \& Chang C.-W. 2012. Otolith Atlas of Taiwan Fishes. National Museum of Marine Biology and Aquarium, Pingtung.

Lin C.-H., Girone A. \& Nolf D. 2015. Tortonian fish otoliths from turbiditic deposits in northern Italy: taxonomic and stratigraphic significance. Geobios 48: 249-261. https://doi.org/10.1016/j. geobios.2015.03.003

Lin C.-H., Nolf D., Steurbaut E. \& Girone A. 2016. Fish otoliths from the Lutetian of the Aquitaine Basin (SW France), a breakthrough in the knowledge of the European Eocene ichthyofauna. Journal of Systematic Palaeontology. https://doi.org/10.1080/14772019.2016.1246112

Nafpaktitis B.G., Backus R.H., Craddock J.E., Haedrich R.L., Robinson B.H. \& Karnella C. 1977. Family Myctophidae. In: Gibbs R.H. Jr. (ed.) Fishes of the Western North Atlantic: 1-299. Memoir of the Sears Foundation for Marine Research, New Haven 7.

Nelson J.S. 2006. Fishes of the World. John Wiley \& Sons, Hoboken, New Jersey.

Nolf D. 1985. Otolithi Piscium. In: Schultze H.-P. (ed.) Handbook of Paleoichthyology 10. Gustav Fischer Verlag, Stuttgart and New York.

Nolf D. 1988. Les otolithes de téléostéens éocènes d'Aquitaine (sud-ouest de la France) et leur intérêt stratigraphique. Mémoire de l'Académie royale de Belgique, Classe des Sciences 19 (2), Royal Academy of Belgium, Brussels.

Nolf D. 2013. The Diversity of Fish Otoliths, Past and Present. Royal Belgian Institute of Natural Sciences, Brussels.

Nolf D. \& Aguilera O. 1998. Fish otoliths from the Cantaure Formation (Early Miocene of Venezuela). Bulletin de l'Institut royal des Sciences naturelles de Belgique, Sciences de la Terre 68: 237-262.

Nolf D. \& Brzobohatý R. 1994. Fish otoliths from the Late Oligocene (Eger and Kiscell Formations) in the Eger area (northeastern Hungary). Bulletin de l'Institut royal des Sciences naturelles de Belgique, Sciences de la Terre 64: 225-252.

Nolf D. \& Brzobohatý R. 2002. Otolithes de poissons du Paléocanyon de Saubrigues (Chattien à Langhien), Aquitaine méridionale, France. Revue de Micropaléontologie 45 (4): 261-296. https://doi. org/10.1016/S0035-1598(02)90049-8

Nolf D. \& Brzobohatý R. 2004. Otolithes de poissons du Miocène inférieur piémontais. Rivista Piemontese di Storia Naturale 25: 68-118.

Nolf D. \& Brzobohatý R. 2009. Lower Badenian fish otoliths of the Styrian and Lavanttal basins, with a revision of Weinfurter's type material. Annalen des Naturhistorischen Museums Wien 111A: 323-356. 
Nolf D. \& Cahuzac B. 2009. Une remarquable association d'otolithes de poissons dans le Miocène moyen de Sos, Matillo (France, Lot-et Garonne). Bulletin de l'Institut royal des Sciences naturelles de Belgique, Sciences de la Terre 79: 191-204.

Nolf D. \& Cappetta H. 1980. Les otolithes de téléostéens du Miocène de Montpeyroux (Hérault, France). Palaeovertebrata 10 (1): 1-28.

Nolf D. \& Cappetta H. 1989. Otolithes de poissons pliocènes du Sud-Est de la France. Bulletin de l'Institut royal des Sciences naturelles de Belgique, Sciences de la Terre 58: 209-271.

Nolf D. \& Cavallo O. 1995. Otolithes de poissons du Pliocène Inférieur de Monticello d'Alba (Piémont, Italie). Rivista Piemontese di Storia Naturale 15: 11-40.

Nolf D. \& Girone A. 2000. Otolithes de poissons du Pleistocène inférieur (Santernien) de Morrona (sud est de Pisa). Rivista Piemontese di Storia Naturale 21: 3-18.

Nolf D. \& Girone A. 2006. Otolithes de poissons du Pliocène inférieur (Zancléen) des environs d'Alba (Piémont) et de la côte ligure. Rivista Piemontese di Storia Naturale 27: 77-114.

Nolf D. \& Girone A. 2008. Early Oligocene fish otoliths from the Castellane area (SE France) and an overview of Mediterranean teleost faunas at the Eocene-Oligocene boundary. Neues Jahrbuch für Geologie und Paläontologie, Abhandlungen 248: 139-157. https://doi.org/10.1127/0077-7749/2008/0248-0139

Nolf D. \& Marques da Silva C. 1997. Otolithes de poissons pliocènes (Plaisancien) de Vale de Freixo, Portugal. Revue de Micropaléontologie 40 (3): 273-282.

Nolf D. \& Reichenbacher B. 1999. Fisch-Otolithen aus brackischen Faziesräumen aus dem MittelEozän von Norditalien und Ungarn. Bulletin de l'Institut royal des Sciences naturelles de Belgique, Sciences de la Terre 69: 187-196.

Nolf D. \& Steurbaut E. 1983. Révision des otolithes de téléostéens du Tortonien stratotypique et de Montegibbio (Miocène Supérieur d'Italie septentrionale). Mededelingen van de Werkgroep voor Tertiaire en Kwartaire Geologie 20: 143-197.

Nolf D. \& Steurbaut E. 2002. Compléments à l'étude des otolithes de poissons rupeliens d'Aquitaine méridionale (Sud Ouest de la France). Revue de Micropaléontologie 45 (4): 297-312. https://doi. org/10.1016/S0035-1598(02)90058-9

Nolf D. \& Steurbaut E. 2004. Otolithes de poissons de l'Oligocène inférieur du Bassin liguro-piémontais oriental, Italie. Rivista Piemontese di Storia Naturale 25: 21-68.

Nolf D., Mane R. \& Lopez A. 1998. Otolithes de poissons du Pliocène inférieur de Papiol, près de Barcelone. Palaeovertebrata 27 (1-2): 1-17.

Přikryl T., Brzobohatý R. \& Gregorová R. 2016. Diversity and distribution of fossil codlets (Teleostei, Gadiformes, Bregmacerotidae): review and commentary. Palaeobiodiversity and Palaeoenvironments 96: 13-39. https://doi.org/10.1007/s12549-015-0222-z

Radwańska U. 1992. Fish otoliths in the Middle Miocene (Badenian) deposits of southern Poland. Acta Geologica Polonica 42 (3-4): 141-328.

Reichenbacher B. \& Cappetta H. 1999. First evidence of an early Miocene marine Teleostean fish fauna (otoliths) from La Paillade (Montpellier, France). Palaeovertebrata 28 (1): 1-46.

Rivaton J. \& Bourret P. 1999. Les otolithes des poissons de l'Indo-Pacifique. Documents scientifiques et techniques, Institut de recherche pour le développement, Nouméa 2 (2): 1-378.

Robba E. 1970. Otoliti del Tortoniano-tipo (Piemonte). Rivista Italiana di Paleontologia 76: 89-172.

Rögl F. 1998. Palaeogeographic considerations for Mediterranean and Paratethys seaways (Oligocene to Miocene). Annalen des Naturhistorischen Museums in Wien 99A: 279-310. 
Rögl F. 1999. Mediterranean and Paratethys. Facts and hypotheses of an Oligocene to Miocene paleogeography (short overview). Geologica Carpathica 59: 339-349.

Schwarzhans W. 2013a. A comparative morphological study of the Recent otoliths of the genera Diaphus, Idiolychnus and Lobianchia (Myctophidae). Palaeo Ichthyologica 13: 41-82. https://doi. org/10.13140/2.1.2872.3843

Schwarzhans W. 2013b. Otoliths from the Miocene of West Africa, primarily from the Mandorové Formation of Gabon. Palaeo Ichthyologica 13: 151-184. https://doi.org/10.13140/2.1.4576.3200

Schwarzhans W. 2014. Otoliths from the middle Miocene (Serravallian) of the Karaman Basin, Turkey. Cainozoic Research 14 (1): 35-69. https://doi.org/10.13140/2.1.1090.6245

Schwarzhans W. \& Aguilera O. 2013. Otoliths of the Myctophidae from the Neogene of tropical America. Palaeo Ichthyologica 13: 81-150.

Schwarzhans W., Bradić K. \& Rundić L. 2015. Fish-otoliths from the marine-brackish water transition from the Middle Miocene of Belgrad area, Serbia. Paläontologische Zeitschrift 89: 815-839. https://doi. org $/ 10.1007 / \mathrm{s} 12542-015-0272-6$

Smale M.J., Watson G. \& Hecht T. 1995. Otolith Atlas of Southern African Marine Fishes. Ichthyological Monographs of the J.L.B. Smith Institute of Ichthyology 1, South African Institute for Aquatic Biodiversity, Grahamstown, South Africa.

Steurbaut E. 1979. Les otolithes de téléostéens des Marnes de Saubrigues (Miocène d'Aquitaine méridionale, France). Palaeontographica A 166 (1-3): 50-91.

Steurbaut E. 1983. Les otolithes de téléostéens de la Formation de Tanaro (Langhien inférieur du Piémont, Italie septentrionale). Geologica et Paleontologica 17: 255-263.

Steurbaut E. 1984. Les otolithes de téléostéens de l'Oligo-Miocène d'Aquitaine (Sud-Ouest de la France). Palaeontographica A 186 (1-6): 1-162.

Steurbaut E. \& Jonet S. 1982. Révision des otolithes de téléostéens du Miocène portugais. Bulletin de la Société Belge de Géologie 90 (3): 191-229.

Violanti D. \& Giraud V. 1992. Contributi allo studio del Neogene delle Langhe sud-occidentali (Mondovi). Rivista Italiana di Paleontologia e Stratigrafia 97 (3-4): 639-660.

Whitehead P.J.P., Bauchot M.L., Hureau J.C., Nielsen J. \& Tortonese E. (eds). 1986-1989. Fishes of the North-Eastern Atlantic and the Mediterranean, 3 volumes. UNESCO, Paris.

Zilch A. 1965. Die Typen und Typoide des Natur-Museums Senckenberg, 31: Fossile Fisch-Otolithen. Senckenbergiana Lethaea 46a: 453-490.

Manuscript received: 4 May 2016

Manuscript accepted: 19 September 2016

Published on: 23 May 2017

Topic editor: Christian de Muizon

Desk editor: Kristiaan Hoedemakers

Printed versions of all papers are also deposited in the libraries of the institutes that are members of the EJT consortium: Muséum national d'Histoire naturelle, Paris, France; Botanic Garden Meise, Belgium; Royal Museum for Central Africa, Tervuren, Belgium; Natural History Museum, London, United Kingdom; Royal Belgian Institute of Natural Sciences, Brussels, Belgium; Natural History Museum of Denmark, Copenhagen, Denmark; Naturalis Biodiversity Center, Leiden, the Netherlands; Museo Nacional de Ciencias Naturales-CSIC, Madrid, Spain. 
Appendix. Generic nomenclature adopted in the present paper for the nominal species of the Tortonian, which were previously reported under open generic nomenclature.

\begin{tabular}{l|l}
\hline Nomenclature in Nolf (2013) and Lin et al. (2015) & \multicolumn{1}{|c}{ This paper } \\
\hline "Ogcocephalida" unicus (Bassoli, 1906) & "Ogcocephalus" unicus (Bassoli, 1906) \\
"Scorpaenida" zibinica (Bassoli, 1909) & "Scorpaena" zibinica (Bassoli, 1909) \\
"Malacanthida" mirabilis (Bassoli, 1906) & "Malacanthus" mirabilis (Bassoli, 1906) \\
"Haemulida" lucida (Bassoli, 1906) & "Haemulon" lucidum (Bassoli, 1906) \\
"Sparida" doderleini (Bassoli \& Schubert, 1906) & "Sparus" doderleini (Bassoli \& Schubert, 1906) \\
"Gobiida" bicornuta Lin, Girone \& Nolf, 2015 & "Gobius" bicornutus (Lin, Girone \& Nolf, 2015) \\
"Gobiida" brioche Lin, Girone \& Nolf, 2015 & "Gobius" brioche (Lin, Girone \& Nolf, 2015) \\
"Gobiida" weileri Bauza Rullan, 1955 & "Gobius" weileri Bauza Rullan, 1955 \\
\hline
\end{tabular}

